Athens Journal of History - Volume 8, Issue 2, April 2022 - Pages 117-146

\title{
Change of Status, Change of Art
}

\author{
By Raluca Prelipceanu*
}

\begin{abstract}
The changes in art and the changes in the status of Orthodox icon painters from Transylvania during the $18^{\text {th }}$ and early $19^{\text {th }}$ centuries are closely linked. This paper looks into the link between the two. During this time, there is an important shift in the condition of the painters from that of mere craftsmen to artists. The main sources used in this paper, besides the paintings themselves and the signatures of the artists are the visitations notes, a few contracts that remain to this day and the painters' biographies. The article first looks into the status of the painters, then it presents the social and political context of the period. These sections are followed by an analysis of the changes at the level of the art and also by a semantic analysis. The change in the status of Orthodox icon painters can be considered not only by looking into the transformation and development of certain iconographic representations, but also by the study of their signatures. Are all these changes due to the desire of icon painters to acquire a better social status, or are they imposed by the donors and the church authorities? This is the main question addressed in this article. In conclusion, the seeking of social status is intertwined with the demands of the donors, both determining the changes in Orthodox church art.
\end{abstract}

\section{Introduction}

“The $18^{\text {th }}$ century witnessed in Transylvania an explosion of Romanian art and the most suggestive evolution took place in the field of painting, 300 painters being active during this period. With confidence and humility they adorned the wooden and stone churches of the Romanians." 1

At the beginning of the $20^{\text {th }}$ century, Ștefan Meteș ${ }^{2}$ and Coriolan Petreanu ${ }^{3}$ were the first historians who wrote about the Transylvanian painters of that time. However, Meteș and Petreanu made a mere review of the painters and their works and not a stylistic analysis. Art historians like I.D. Ștefănescu did not even consider this period in their research because of Western influences that entered the traditional Orthodox art. Neither did Vasile Drăguț and Virgil Vătășianu, other two well-known art historians, who focused only on medieval art. However, later art historian Marius Porumb ${ }^{4}$ analyzed the artistic milieu of the $18^{\text {th }}$ century. Also, some historians published several monographs of some of the Transylvanian

*Graduate Student, University of Babes Bolyai Cluj Napoca, Romania.

1. Marius Porumb, Un Veac de Pictură Românească din Transilvania, Secolul XVIII (București: Meridiane, 2003), 5.

2. Ștefan Meteș, "Zugravii Bisericilor Române," Anuarul Comisiunii Monumentelor Istorice, secția pentru Transilvania 1926-1928, Cluj, (1929).

3. Coriolan Petreanu, Bisericile de Lemn ale Românilor Ardeleni (Sibiu, 1934).

4. Porumb, Un Veac de Pictură Românească din Transilvania, Secolul XVIII, 2003. 
painters during that time, like those about Iacov of Răşinari, ${ }^{5}$ Stan of Rășinari, ${ }^{6}$ Toader Popovici, ${ }^{7}$ Grigore Ranite, ${ }^{8}$ as well as articles about painters like Simion Silaghi, ${ }^{9}$ Ursu Broină, ${ }^{10}$ Stefan Tenecki, ${ }^{11}$ etc.

Unfortunately, their research takes very little into account the possible interactions between painters and oftern does not perform an in-depth analysis of the changes occuring during that period, nor does it look into the broader context of the Orthodox painters under Habsburg rule. The current article tries to fill in this gap by discussing the mobility of painters, their social status, thus shedding light on the possible interactions and sources of change. The article attempts to establish a link between the changes in art during this time and the changes in the social status of the painters. This research is based on both visual and written sources.

\section{Painters' Origin and Status}

Most of the painters were Romanians, but some came from the neighbouring regions and mostly from the Orthodox communities under Habsburg rule. The circulation of painters to Transylvania is not a new phenomenon. During the Middle Ages several painters embellished the Transylvanian churches with beautiful frescoes. Some of them were from the neighbouring Romanian lands: Wallachia and Moldavia, while others came from the Western world. Even the supposedly local painters, such as Mihul from Crișul Alb, who during the $14^{\text {th }}$ century decorated with frescoes the church of the Râmeț monastery seem to have come from Serbia or to have studied under Serbian painters. ${ }^{12}$ While at Râmeț the style is mostly Byzantine, in other Transylvanian churches from the $14^{\text {th }}$ and $15^{\text {th }}$ centuries, like those of Strei, Ribița and Crișcior, the Byzantine style coexists with

5. Ana Dumitran, Elena Cucui, Elena Mihu and Saveta Pop, Iacov Zugravul (Alba Iulia: Ed. Altip, 2010).

6. Dumitran et al., Stan Zugravul (Alba Iulia: Ed. Altip, 2011).

7. Vasile Mureșan and Marcel Naste, Toader Popovici Zugravul (Târgu Mureș: Ed. Vatra Veche, 2015.

8. Dumitran, "Un Zugrav de Elită: Grigore Ranite," Annales Universitatis Apulensis, Series Historica 14, no. I (2010).

9. Dumitran, "Pictorul Simion Silaghi-Sălăgeanu. În căutarea identităţii," Annales Universitatis Apulensis, Series Historica 16, no. I (2012).

10. Silvia Marin Barutcieff, "Un pictor transilvănean pierdut...? Ursu Broină," Apulum, no. 50 (2013).

11. Horia Medeleanu, "The Life of an 18th Century Painter: Stefan Tenetchi," Revue des Études Sud-Est Européennes XXI-2 (1983).

12. Dumitran, "The Chronology of the Murals in the Râmeț Monastic Church. Based on a Re-evaluation of the Dating of the Narthex Inscription," Museikon 4 (2020). 
the Gothic and Neo-Gothic Western styles of the Catholic churches of the same period, like those in Sântana de Mureș, Mălâncrav, Dârlos, etc. ${ }^{13}$

In the $17^{\text {th }}$ century most of the churches in Northern and Central Transylvania were destroyed during the Tatar and Ottoman invasions. The last great Tatar invasion took place in 1717 and a lot of churches in Northern and Central Transylvania were destroyed on that occasion ${ }^{14}$. At the same time, the Reformed princes of Transylvania were not in favour of icons. In a letter to the Russian Emperor, Metropolitan Sava Brancovici, the head of the Orthodox church of Transylvania asked for money in order to rebuild the Metropolitan church of Alba Iulia which had been destroyed for the third time in a century. The Reformed princes of Transylvania were this time responsible for its destruction ${ }^{15}$. At the beginning of the $18^{\text {th }}$ century the Jesuit Joseph de Camillis wrote that most of the icons from the Orthodox churches had been destroyed by order of the Reformed Transylvanian princes. ${ }^{16}$ However, historian Ana Dumitran does not agree with this statement arguing that the production of icons during this period was still important. ${ }^{17}$

Some Ruthenian, but also Moldavian painters were active in Transylvania during the $17^{\text {th }}$ century. Vasili Stașoschi worked at Lujderiu ${ }^{18}$, while Nicolaus Polonii painted the nave of the church in Săliștea Sibiului in 1674 and Grigori ot Colomii painted two icons for the monastery at Deda in $1690^{19}$. Also, the local artist, Mihail from Hunedoara decorated the church at Cincis in the middle of the century $^{20}$. Furthermore, there are some other icons dating from that period, which though not signed, can be attributed either to Ruthenian or Moldavian itinerant painters. The priest Luca of Iclod, the painter of the wonder-working icons of the Holy Mother of God from Nicula (1681), Ilișua (1673) and Strâmba, also seems to have been of Ruthenian origin as his style was close to that of the school of Halicz in Ukraine ${ }^{21}$. In an official document of the time he was called "gente Ruthenus".

13. Dana Jenei, Pictură Murală Gotică din Transilvania (București: Noi Media Print, 2007).

14. Ioana Cristache Panait, "Tipuri sociale și aspecte de critică socială în pictura monumentelor de lemn din centrul și vestul țării," RMM, MIA XV, no. 1 (1984): 54.

15. Silviu Dragomir, Contribuţii Privitoare la Relațiile Bisericii Româneşti cu Rusia în Veacul XVII. (București: Academia Română, 1912).

16. Ovidiu Ghitta, "Episcopul Iosif de Camillis și Românii din Părțile Ungurești," Studia Universitatis Babeș Bolyai 42, no. 1-2 (1997).

17. Dumitran, “Între Logos și Eikon. Un Eseu Despre Icoană, Români și Protestantism în Transilvania Secolului al XVII-lea," in Annales Universitatis Apulensis, Series Historica, 18/I (Cluj Napoca: Ed. Mega, 2014)

18. Museikon, Time, Faith, Heritage, (Alba Iulia, 2017), 20

19. Dumitran, Între Logos și Eikon, 127.

20. Ibid, 131.

21. Ibid, 122. 
During the following century several painters from Wallachia worked in Transylvania such as David from Curtea de Argeș or Simion from Pitești. The latter signed the paintings of Densus, Prislop and the iconostasis in Gurasada. The throne icon of the Virgin at Prislop monastery was painted by the Wallachian Ioan ot vel Ocna in 1752. Also, Simion's apprentice, Nicolae from Pitești worked at Gurasada. Painter Simion Oprovici from Craiova was also working in Transylvania in 1772. Also, the famous Wallachian painter Grigore Ranite and his son, Ioan Grigoriovici worked in Transylvania and Banat during the $18^{\text {th }}$ century. ${ }^{22}$

Considering the decorations and the long faces that he painted, Ana Dumitran argued that Master Andrei Bo(...)dor from Cluj was also of Ruthenian origin. ${ }^{23}$ Another painter of Ruthenian origin who worked in Transylvania during the $18^{\text {th }}$ century was Vasile Zboroschi who painted the iconostasis of the church in Certege in $1752 .{ }^{24}$

Figure 1 presents The Holy Martyrs painted in the nave of the church in Bica by Simion Silaghi and Andrei Bo(...)dor containing the traditional decoration of Ruthenian influence.

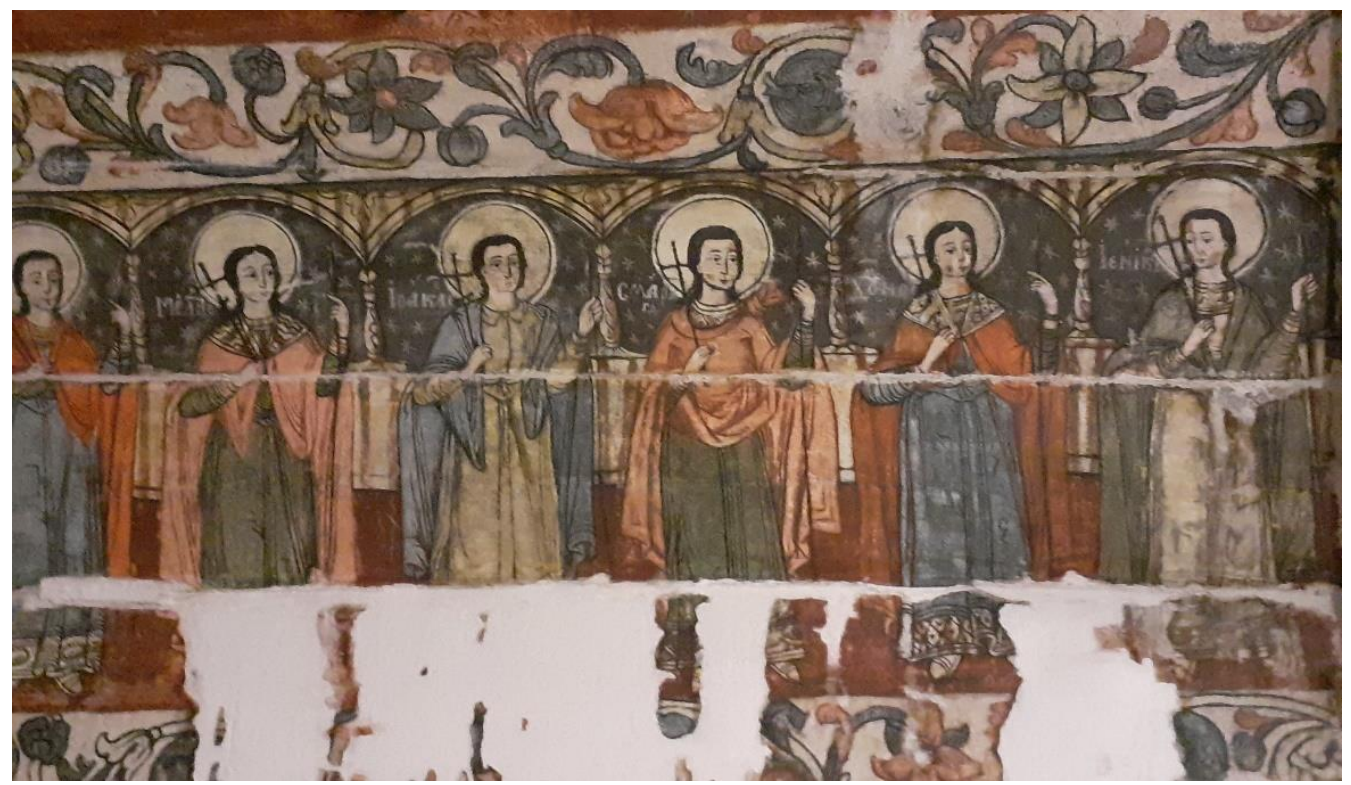

Figure 1. The Holy Martyrs, Bica, Simion Silaghi and Andrei Bo(...)dor,1775

A famous painter Constandinos, of Greek origin established in Brașov where he opened a workshop. Moreover, painters from Banat, like Stefan Tenecki also

22. Meteș, “Zugravii Bisericilor Române,” 1929, 128.

23. Dumitran, "Pictorul Simion Silaghi-Sălăgeanu. În Căutarea Identității," 2012, 190.

24. The inscription reads: 'This holy icon was paid for by Opria Constandin and wife Ioana from Lupsa 1752': "Aiastă sfântă icoană o plătit Opria Constandin cu soțu său Ioana, din Lupșa. 1752". 
worked in Transylvania, as did the painters from Maramuresh, Alexandru Ponehalschi and Radu Munteanu.

After the treaty of Karlowitz, at the end of the $17^{\text {th }}$ century, Transylvania came under Habsburg rule. However this did not improve much the position of the Romanian population, traditionally Orthodox who had no social rights and no social recognition. The condition of the Orthodox painters from Transylvania was that of mere artisans. Probably, like the neighbouring Ruthenian painters they could not earn their living only by their art, they were also involved in other activities. A writer from Ostroh wrote in 1588 that "before, there were excellent, pious painters of icons, but now icon painting is dominated by saddlers, bridlemakers, and other clowns" ${ }^{25}$

At the beginning of the $18^{\text {th }}$ century some of the painters still came from the monastic orders, like Gheorghe the monk and Iosif the hieromonk. ${ }^{26}$ The same state of affairs occurred in neighbouring Ruthenia. However, during the $18^{\text {th }}$ and early $19^{\text {th }}$ centuries most of them were lay painters or clerics, like popa Ivan of Rășinari, popa Gheorghe Tobias from Abrud, popa Nicolae of Feisa, popa Ioan Grigoriovici.

Painters did not come from poor families. Marius Porumb ${ }^{27}$ thinks that Simion Silaghi might have actually come from the ranks of the petty gentry, while the famous painters Iacov and Stan of Rășinari were the sons of priest Radu Man. ${ }^{28}$ Dynasties of painters were formed. This was the case of the families of painter Iacov from Rășinari, whose sons Gheorghe and Nicolae were also painters. Toader Ciungar's sons Iacov and Nicolae were equally painters, as were Simion Silaghi's three sons: Gavriil, Simion and Partenie and even his grandson, Isidor. The skill was thus passed on from generation to generation following an initiation ritual.

\section{Painting Schools in $18^{\text {th }}$ Century Transylvania}

Several painting schools developed during the $18^{\text {th }}$ century, but the only guild recorded was that of 'the painters on paper' from Gherla. The only attempt to gather into a guild by other painters was made in Banat in 1736. In 1756 a group of five painters including Gheorghe Ranite, Nedelcu and Şerban Popovici demanded protection from the bishop of Timișoara against the competition of the

25. Lilya Berezhnaya and John Paul Himka, The World To Come. Ukrainian Images of the Last Judgement (Harvard University Press, 2015).

26. Meteș, "Zugravii Bisericilor Române," 1929, 116.

27. Ibid, 368-372.

28. Porumb, Dicționar de Pictură Veche Românească (București: Ed. Academiei Române, 1998), 169. 
itinerant painters, which suggests the extent of painters' mobility during that time. ${ }^{29}$

One of the most important painting schools was undoubtedly that of Feisa established by Iacov of Rășinari ${ }^{30}$ who moved there in 1762 . His sons, Gheorghe and popa Nicolae were among its representatives, as was another important painter Toader Popovici. The family of Iacov had close links with the famous Wallachian painter Grigore Ranite ${ }^{31}$ Both Stan and Iacov had painted with him at Curtea de Argeș and, according to the records, Ranite became Iacov's godfather. Later, Stan also opened his own workshop in Orăștie.

Figures 2 and 3 show two of the most famous icons painted by Iacov Zugravul. Like the ancient Byzantine painters the signature of the artist is hidden among the details of the painting, ${ }^{32}$ in this case the decoration of the throne.

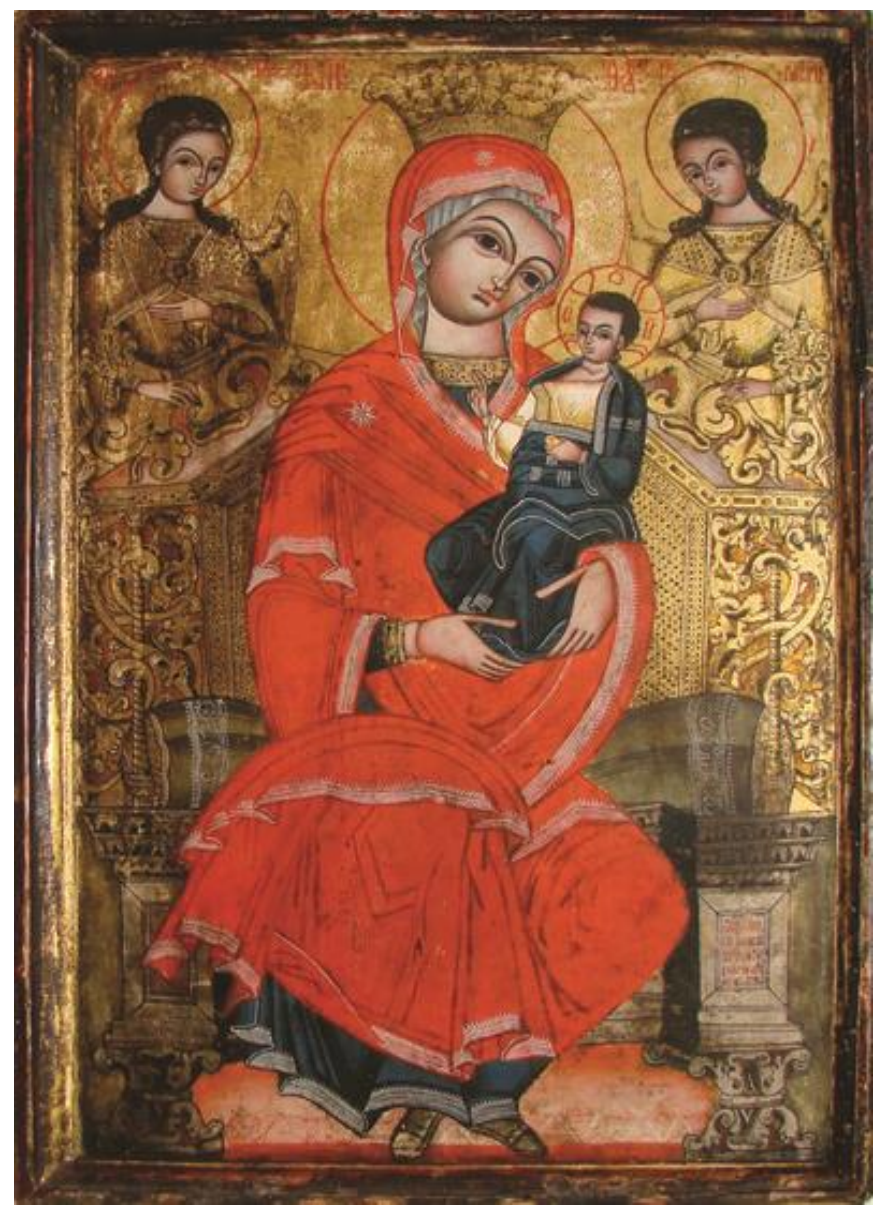

Figure 2. The Holy Mother of God, Iacov Zugravul 1746

29. Meteș, “Zugravii Bisericilor Române,” 1929, 131.

30. Dumitran, Cucui, Mihu and Pop, Iacov Zugravul, 2010, 13.

31. Ibid, 1.

32. Sophia Kalopissi Verti, "Painters in Late Byznatine Society. The Evidence of Church Inscriptions," Cahiers Archeologiques 42 (1994). 


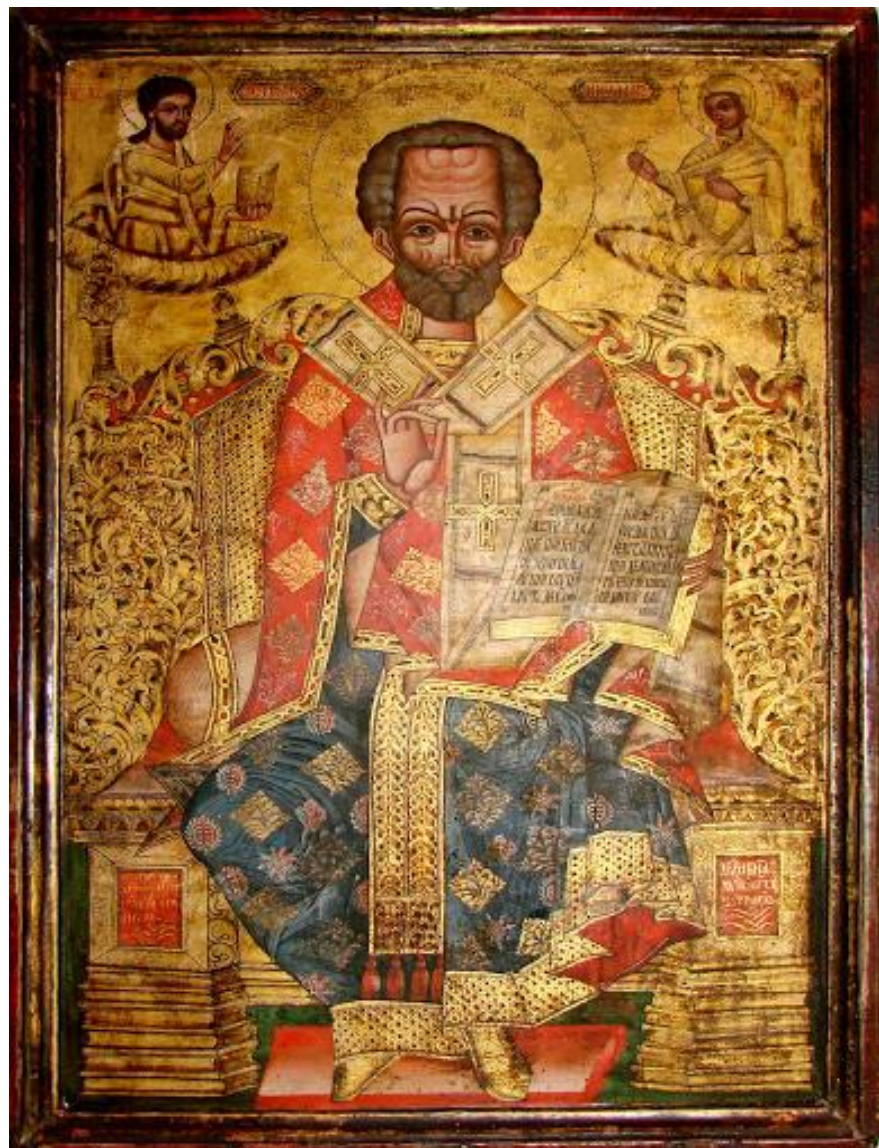

Figure 3. Icon of St Nicholas, Iacov Zugravul 1745

Grigore Ranite was one of the most illustrious representatives of the neoByzantine style which had developed in Wallachia under the reign of martyr Prince Constantin Brâncoveanu (1688-1714). Ranite came from Craiova. In Wallachia he painted the monastery of Tismana, the church of Vădeni, the skete of Crasna, the monastery of Sărăcinești, the bishopric chapel in Râmnic. He also worked in Transylvania at the painting of the Black Church of Braşov (1733-1734), that of St Paraschiva church in Rășinari (around 1758) and at the Greek Catholic bishopric cathedral of Blaj (1736). Several eschatological images were introduced by Ranite in his iconographic programmes.

The development of such relations prove the existence of close artistic links between the southern part of Transylvania and Wallachia that date back many centuries and can be traced at least starting with the $14^{\text {th }}$ century.

Figure 4 presents the Wheel of Life painted by Grigore Ranite at the church in Rășinari. 


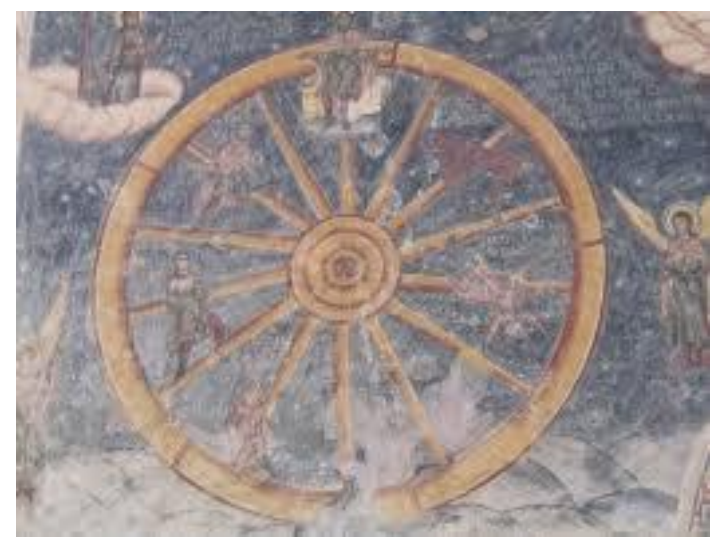

Figure 4. The Wheel of Life Represented by Grigore Ranite at the Black Church in Braşov 1733-1734 and at St Paraschiva church in Rășinari 1758

Simion Silaghi's school in Abrud was one of the most important schools at the turn of the century. Simion Silaghi had many apprentices; first of all his three sons, but also other painters from the region of Apuseni where he resided. Among them were Ion and Nicoale Cuc, Nicolae and Nechifor Bădău, Gheorghe Șpan, Motok Karoly. Before Silaghi, another well-known painter and Greek Catholic priest of the $18^{\text {th }}$ century had worked in Abrud, Popa Gheorghe Tobias. Gheorghe Tobias's painting is a mixture of neo-Byzantine elements and Western influences.

The school in Laz, in Southern Transylvania was also important. In Laz, the tradition has been handed down from father to son or from uncle to nephew to this day. The first generation of painters from Laz, Savu and Simion painted both fresco, icons on wood and on glass. Later, the painters from this school focused only on glass icons, like the painters from the neighbouring school of Lancrăm.

The neighbouring regions of Maramuresh and Banat had their own painting schools. Alexandru Ponehalschi was one of the most important painters in Maramuresh. He was of Ruthenian origin, but he had Romanian apprentices. In Banat painters of Serbian origin worked alongside Romanian painters. Some of the most famous Serbian painters were Stefan Tenecki, Nedelcu Popovici, Toader Crăciun, Nikola Nescovici, Petrar Nicolici, etc. Sometimes painters from other areas also received commissions in Transylvania. They either travelled there, or they worked on the commissions they received in their own workshops and later delivered them to their donors.

Figure 5 depicts Christ painted by Stefan Tenecki for the altar of the Greek Catholic cathedral in Blaj. 


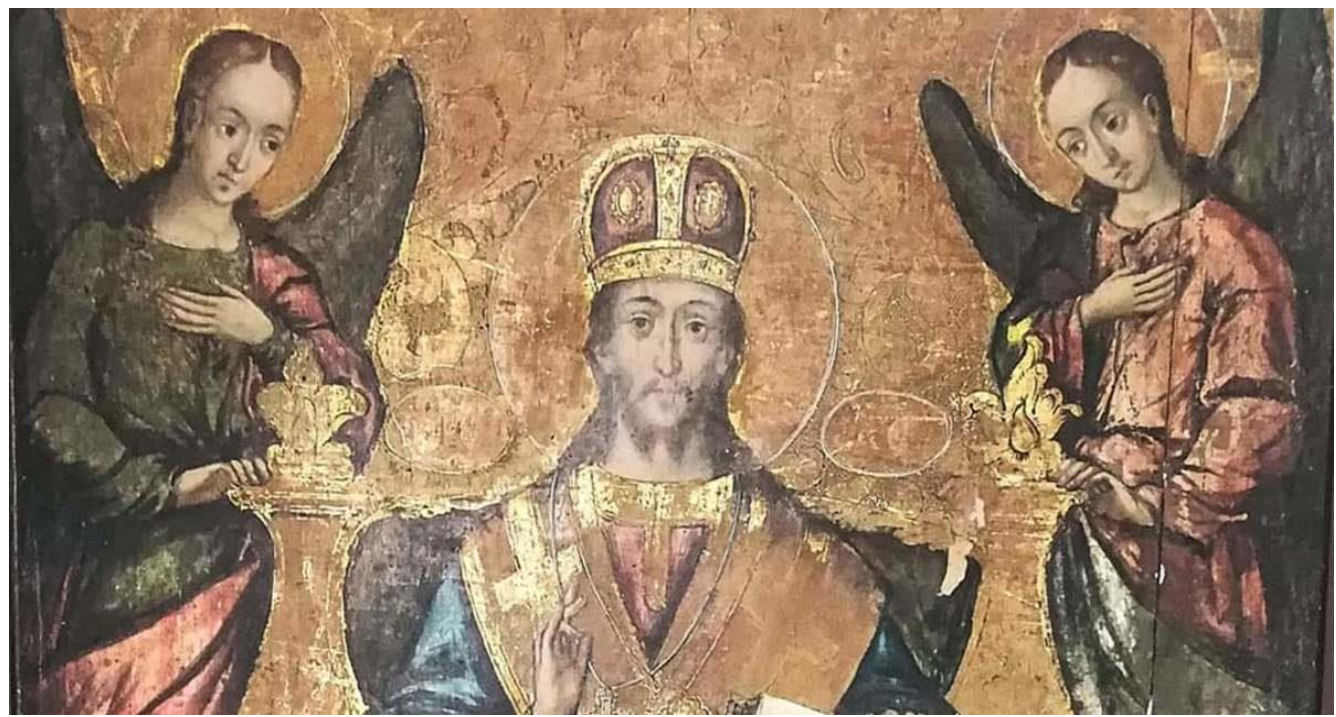

Figure 5. The Altar of the Greek Catholic Cathedral in Blaj by Stefan Tenecki, 1765

\section{The Political and Social Context}

The $18^{\text {th }}$ century in Transylvania was characterized by the Romanians' fight to be recognized as a nation with the same rights as the other nations living in this land. The new Habsburg domination lifted up the hopes of the Romanians living in Transylvania. The unity with the church of Rome in 1701 served this aim. Following this step, some of the Orthodox churches passed under the possession of the new Greek Catholic church. However, Romanians did not receive the same rights as the other nations and in mid-1740s a Serbian monk called Visarion Sarai drew attention on the betrayal of the true Orthodox faith by the bishop and the priests. He was active in Southern Transylvania. Following his initiative, several demands and petitions in favour of returning to the Orthodox faith were written and presented to the Empress Maria Theresa. The lack of response brought about serious unrest and discontent which reached a peak with the uprising under monk Sofronie of Cioara in 1760-1761. During the uprising several Orthodox churches were destroyed, but finally the Empress admitted the Orthodox faith and placed the Orthodox in Transylvania under the jurisdiction of the Serbian Metropolitan of Karlowitz in $1761 .{ }^{33}$ Romanian Orthodox did receive some rights after the decree of tolerance passed by Emperor Joseph II in 1782, including the right to build stone churches.

The fight did not enjoy the same success on the social dimension so a new uprising took place in 1784 in the Apuseni Mountains. Romanians did not

33. Ljubivoje Cerovič, Sârbii din România. Din Evul Mediu până în Zilele Noastre (Timișoara: Uniunea Sârbilor din România, 2008), 66; Paul Brusanowski, "Statutul Canonic al Ortodoxiei din Spațiul Intracarpatic până în 1864," Revista Teologică 20, no. 92 (2010): 95-113. 
demand the abolition of social classes, however they fought for equal rights with the other nations. The heads of the uprising were caught and executed in the capital city of Transylvania, Alba Iulia in 1785.34

The Metropolitan of Karlowitz, Arsenie IV Jovanovic was concerned with the priests' and the believers' education level, therefore in 1733 he opened an academy in Karlowitz where painting was also taught. ${ }^{35}$ While the first official painters of the Metropolitanate had studied with Russian teachers, the next generation was taught by teachers from Kyiv Caves Lavra. Painters such as Stefan Tenecki from Lipova, considered the court painter of the bishop of Arad were educated at the Caves Lavra and possibly also at the Vienna Academy. The teaching dispensed at the Caves Lavra covered many topics, in addition to iconography, students also studied portrait art and monumentalistic painting. ${ }^{36}$

The Orthodox Serbs had been granted privileges that other Orthodox nations under Habsburg rule did not enjoy. This explains why they were more open to Western influences. ${ }^{37}$ At the same time, the Russian teachers invited to Karlowitz by the Metropolitan were under the influence of Tsar Peter's reforms of 1722 published in a Gramata. ${ }^{38}$ The teachers from the school of the Kyiv Lavra, now in Imperial Russia were also influenced by Western art as many Western models were studied there.

There were two directions of change in the art of the Lavra: one coming from the newly formed Greek Catholic Ruthenian church which adopted Catholic models. The first polemical writings about the paintings of the Orthodox churches were written during the $18^{\text {th }}$ century. Until then, there were no clear differences between the Orthodox and the Catholic churches, although the Union of Brest ${ }^{39}$ had taken place at the end of the $16^{\text {th }}$ century. Many of the churches often changed their canonical jurisdiction and some Orthodox churches were transformed, receiving a choir or a tribune. At the council of Przemysl in 1693, the church authorities remarked that there was chaos at the level of church organization. A new Council which took place in Zamosc set some rules for liturgical services and

34. David Prodan, Supplex Libellus Valachorum. Din Istoria Formării Națiunii Române (București: Ed. Enciclopedică, 2013), 245.

35. Vladimir Cvetkovic, "The Serbian Tradition," in The Orthodox Christian World (ed.) Augustine Casiday (London: Routledge, 2012), 135.

36. Philip Zweig, Icônes, XI-XVIII Siècles (New York: Parkstone International, SUA, 2004), 116.

37. Remus Câmpeanu, A. Câmpian, et al. În Spiritul Europei Moderne. Administrația și Confesiunile din Transilvania în Perioada Reformismului Terezian și Iosefin (1740-1790) (Cluj Napoca: Presa Universitară Clujeană, 2009).

38. Waldemar Deluga, Ukrainian Painting Between the Byzantine and Latin Traditions (Ostrava-Warsaw 2019), 115.

39. Deluga, "L'évolution de l'iconographie dans l'église Gréco-Catholique Pendant le XVIII-ieme Siècle à la Lumière des Sources Ecrites," Revue des Etudes Slaves LXXI, no. 2 (1999): 225-242. 
church painting. The report of this council was published in Vilnius and Suprasl in 1722 and later in Univ, Liov and Poceaev. The Council of Zamosc ${ }^{40}$ equals in importance the Catholic Tridentine Council for the Ruthenian Greek Catholic church. Some of its decisions were also implemented by the Orthodox church. As a consequence, Baroque decorations started to adorn Orthodox icons. The iconostasis also became higher, while in some places it disappeared completely.

New subjects were now introduced in Orthodox art. Among these changes are the development of the iconography of the Passions of Christ with an important number of scenes introduced and a special emphasis put on Flagellation. Christ's feet on the cross were seperate and pierced by nails. Furthermore, some Catholic saints began to be represented as well. Also, compositions like Mater Dolorosa and the three Persons of the Holy Trinity became common and even the three-faced Trinity was sometimes represented. Furthermore, Christ and the Virgin were usually crowned and Christ started to be depicted with the orb and the stick as attributes of power.

On the other hand, the Orthodox tried to meet the Catholic attempts to gain control over the church in Ruthenia and they employed Protestant carvers and printers.

One of the main sources of inspiration of the painters during that time was precisely wood carvings or woodcuts, engravings and Blockbücher. ${ }^{41}$ There was a great mobility of engravers during the $17^{\text {th }}$ and $18^{\text {th }}$ centuries in the Romanian space. The prince of Moldavia, Peter Mohyla became Metropolitan of Kiyv in 1632. ${ }^{42}$ He reformed the Ruthenian Orthodox Church and established several printing houses and several schools. The most important was the school of the Kyiv Caves Lavra. Though, a faithful Orthodox he had been educated in Catholic schools either in France or in Poland and his aim was to build a school in Kyiv which later was granted by Emperor Peter I the title of academy. As he had been educated at the Jesuits, he applied there the model of the Jesuit Catholic schools. ${ }^{43}$

The main allies of the Orthodox during their fight for recognition were the Protestants. They had the same enemy, the Catholic Jesuits. Therefore some of the Orthodox printers employed by prince Ostrozky at the end of the $16^{\text {th }}$ century or by Peter Mohyla later, in order to develop and publish a polemical literature, were actually Protestants who were already skilled at their debate against the Catholics. ${ }^{44}$ This is how images by engravers such as Albrecht Dürer, Lucas Cranach and Hans Holbein the Younger ${ }^{45}$ entered Orthodox iconography. This

40. Ibid, 229-230.

41. Deluga, Ukrainian Painting Between the Byzantine and Latin Traditions, 2019, 147-170.

42. Ihor Sevcenko, "The Many Worlds of Peter Mohyla," Harvard Ukrainian Studies 8, no. $1 / 2$ (1984): $9-44$.

43. Ibid.

44. S. Plokhy, Porțile Europei. O Istorie a Ucrainei (București: Ed. Trei, 2018), 100-101.

45. Deluga, Ukrainian Painting Between the Byzantine and Latin Traditions, 2019. 
kind of drawings was actually taught at the painting school at the Caves Lavra. ${ }^{46}$ Some of the most important works that inspired the painters were Biblia Ectypa, Thesaurus, Theatrum Biblicum and Biblia Piscator. ${ }^{47}$

Peter Mohyla also sent teachers as well as printers and wood carvers to Wallachia and Moldavia where his father and uncle had been princes. They mainly reprinted the books that had been printed in the Ruthenian lands only a few years before and reproduced the same wood carvings. He also sent books to Transylvania.

Later, abbot Ioan of Hurezi also encouraged paintings inspired by engravings during his administration of the Wallachian monastery of Hurezi in 1720s. ${ }^{48}$ This also contributed to the adaptation to painting of some of the images engraved.

Therefore, at the Metropolitanate of Karlowitz, the style was set by the Kyiv School Lavra, combined with the Western influences coming from the Vienna painting academy. Besides the painting schools, the canonical visitations of the bishops also contributed to the spreading of new ideas as they could give directions regarding to what could and what could not be represented in churches. Moreover, the priests who were ordained by Serbian bishops in Buda, Arad or Timișoara were probably instructed before their ordination as the Metropolitanate of Karlowitz was also concerned with the art promoted in churches and with the message delivered to the faithful.

However, most of the painters were not educated in official schools, such as the School of the Caves Lavra, the one in Karlowitz or the Academy in Vienna, but in private workshops.

Were there any painting manuals at that time? There are no records of the painting manuals used, though at that time some painting manuals already existed. The books were transmitted only inside the workshop and were left as a legacy to the following generations. The first such book in the Romanian space was the one composed by Metropolitan Antim of Wallachia at the beginning of the $18^{\text {th }}$ century. ${ }^{49}$ Some versions of this manual might have reached Transylvania. Another manual made up between 1733 and 1735 belonged to monk David from Brașov. ${ }^{50}$ Moreover, several sketch notebooks from that time still remain, like those by painter Stan from Orăștie or those by Ștențel Condrat from Bistrița. The sketch notebooks were left as legacy as well and inherited by the painters in the workshop.

46. Zweig, Icônes, XI-XVIII Siècles, 2004, 116.

47. Deluga, "L'évolution de l'iconographie dans l'église Gréco-Catholique Pendant le XVIII-ieme Siècle à la Lumière des Sources Ecrites," 1999, 233.

48. Ioana Iancovescu, "Les Sources Russes et Ukrainiennes de la Peinture Murale au Temps de Constantin Brancovan," Revue Roumaine de l'histoire de l'art, Série Beaux-Arts, Tome XLV (2008): 101-116.

49. Meteș, “Zugravii Bisericilor Române,” 1929, 19-24.

50. Ibid. 
The scenes developed at that time were inspired by the scriptures and the apocryphal literature. The legend of the fourth magus was depicted in the Crucifixion scene and several other apocryphal texts were very influential as well. One of the most important was the Apocalypse of Basil the New which contained a thorough description of the torments suffered by the sinners in hell that inspired many Last Judgement compositions..$^{51}$

As they aspired for a new social status, Orthodox painters, were influenced by the official Catholic painters of the Imperial Court and their ideas. Baroque influences and Western Catholic elements were thus introduced in the Orthodox art.

\section{Changes in Orthodox Art}

How did the changes manifest? First, Western influences penetrated the religious art and can be observed in the iconographic programmes. Marian scenes were represented more often, as the Virgin was the main saint promoted by the Jesuit Counter Reformation propaganda in the fight against the Protestants. Both the Catholic and the Orthodox had a special reverence for Virgin Mary. She was represented in Orthodox iconographic programmes of the $16^{\text {th }}$ century in a developed cycle, especially that of the Akathistos hymn. However, the Reform had forbidden the representations of the Virgin. The churches that still stand from that period have a very simple iconographic programme depicting merely the Passions of Jesus with a narrative and didactical function, like for example the church in Strâmba monastery, now in the county of Sălaj.

Also, though forbidden by Orthodox canons, as stated by the council of Moscow in the $17^{\text {th }}$ century, ${ }^{52}$ the representation of God the Father can be found in most of the churches of the time.

Images promoted by the Catholic Counter Reformation are depicted in most of the Orthodox churches during that period like the Coronation of the Virgin Mary. The image of the Coronation of Mary illustrates the doctrine of the Immaculate Conception and was promoted especially after the Tridentine Council. Due to her Immaculate Conception the Virgin is raised with her body to heaven after death where she is crowned either by Christ or by the Trinity. Also, another image that developed following the Tridentine Council in 1545-1563 was the image of the Virgin of the Immaculate Conception represented as Maria in sole, the Woman of the Apocalypse. Mary redeems humanity, delivering it from Eve's sin, therefore she is

51. John-Paul Himka, Last Judgement Iconography in the Carpathians (University of Toronto Press, 2009), 46-49.

52. Leonid Uspenski, Teologia Icoanei în Biserica Ortodoxă Rusă (Cluj Napoca: Ed. Patmos, 2005). 
represented in opposition to Eve with the attributes of the Woman of the Apocalypse, like the crescent or the twelve stars. ${ }^{53}$

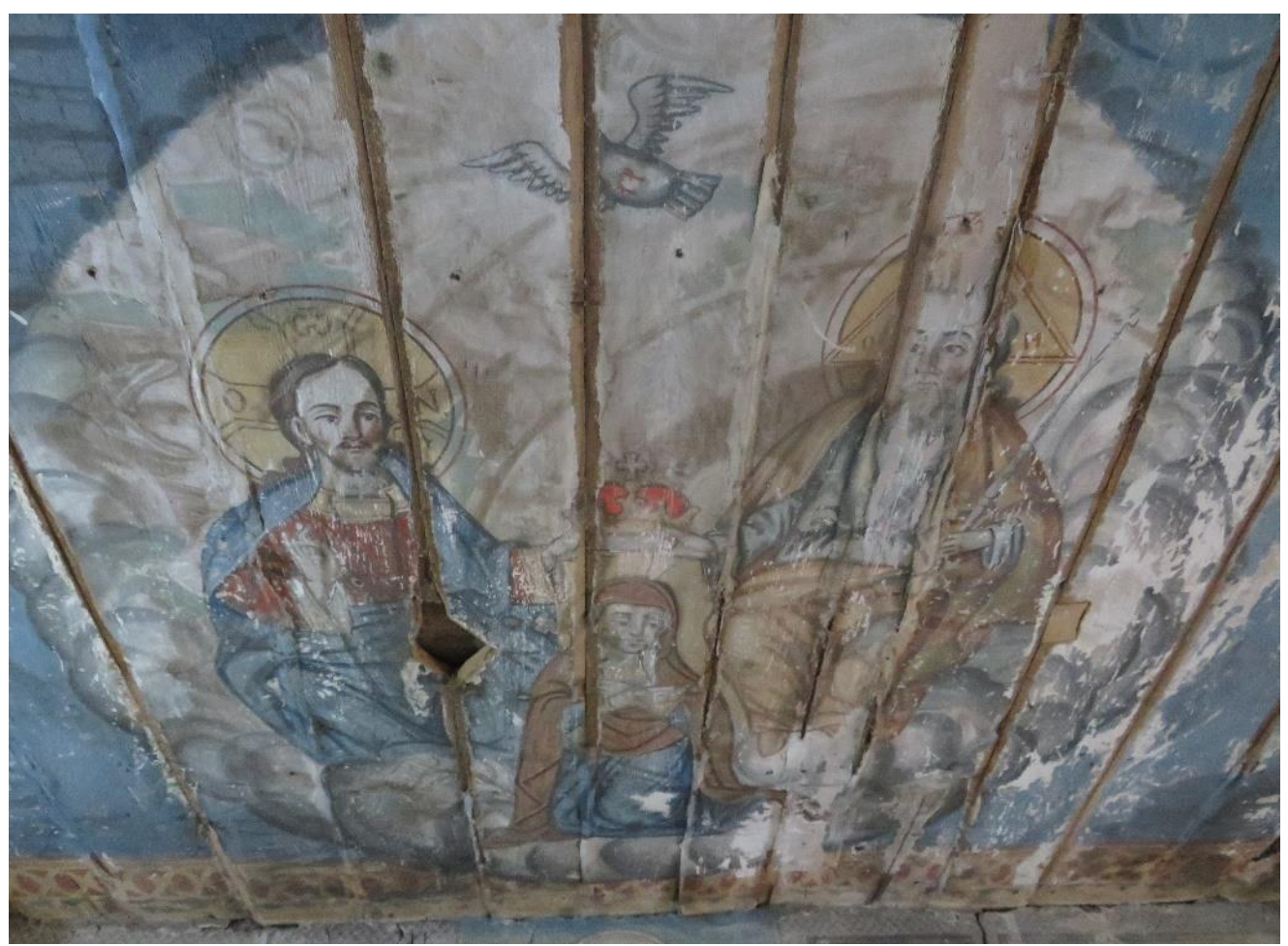

Figure 6. The Coronation of the Virgin by the Holy Trinity, St. Michael Church in Vința, Simion Silaghi, 1819-1821

Figure 6 shows the Coronation of the Virgin painted by Simion Silaghi in the vestibule of the church of Vința between 1819 and 1821. The Virgin is crowned by the Holy Trinity, God the Father, Christ and the dove of the Holy Ghost. The Virgin kneels and she wears the traditional Orthodox maphorion.

Furthermore, in Orthodox art the Virgin is never represented bare headed, her head is always covered, which is not the case in some $18^{\text {th }}$ century compositions. She is also never crowned, like in the case of the Coronation of the Virgin or in some compositions of the Virgin enthroned with Christ child painted in the apse of some churches during that time. Judith Herrin ${ }^{54}$ explains that in the Byzantine Empire there was already an earthly empress wearing a crown and though her garment is very rich, the Virgin is practically never painted with a crown because she would have competed with the empress. In the West there is no empress, therefore there was no such competition.

53. Louis Réau, Iconographie de l'art Chrétien. Tome II Iconographie de la Bible (Paris: PUF, 1957), 622.

54. Judith Herrin, “The Imperial Feminine in Byzantium," Past\&Present, no. 169 (2000): 3-35. 
Other images from Orthodox iconographic programmes are either replaced or transformed. For example, the Virgin in the Annunciation scene is no longer painted seated: instead she is reading a book, an image inspired by the Catholic religious paintings from the Medieval period and promoted by the CounterReformation. The image lays emphasis on the importance of praying, schooling and the knowledge of the Holy Scripture. It also promotes Mary as a learned scholar, a model for the pious believers. ${ }^{55}$ Figure 7 shows the Annonciation painted by Gheorghe son of Iacov in the apse of the church in Mogoș. The Virgin is seated before a table on which lie a book and a scroll. The buildings are painted in Baroque style and also the Holy Ghost is painted as a dove that descends upon the Holy Virgin.

The scenes of the Passions of Christ were constantly represented in all iconographic programmes. However, the episodes of Christ's suffering do not have the same dramatic accents as in the Western art. Christ is filled with joy even when he is raised on to the cross.

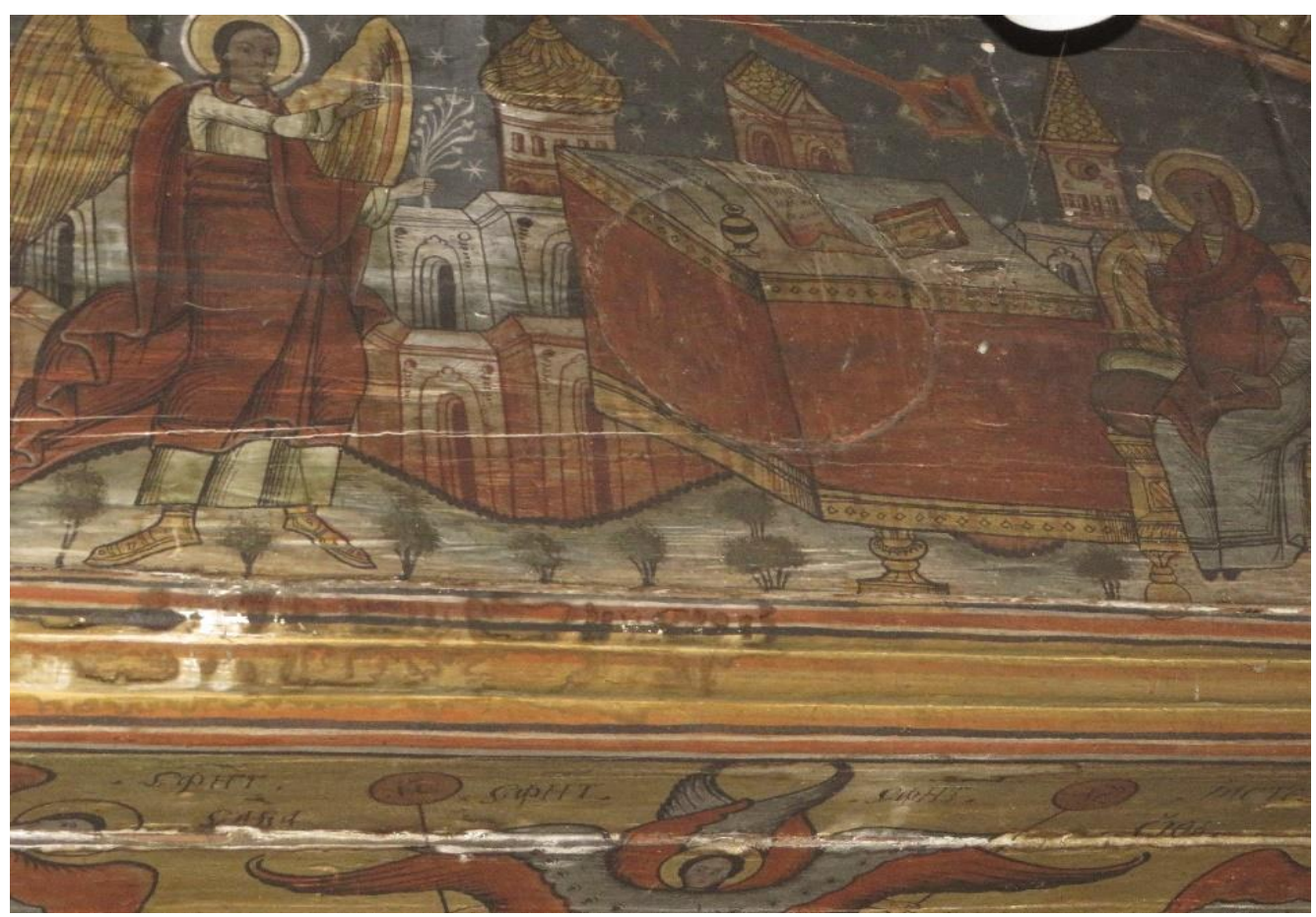

Figure 7. The Annunciation, Apse, St. Archangels Church in Mogoș Cojocani, Gheorghe son of Iacov, 1771

The Assumption also borrows a lot from the Catholic doctrine as the soul of the Virgin is represented often according to the Catholic dogma, already in heaven

55. Laura Saetveit Miles, The Virgin Mary's Book at the Annunciation: Reading, Interpretation, and Devotion in Medieval England (D.W. Brouwer, 2020). 
with Christ, rather than according to the traditional Orthodox representations where Christ holds in his arms her soul, as a pure child, next to the bed on which the Virgin rests.

Also, the image of the Weeping of the Mother of God or Mater Dolorosa is painted very often. Although some researchers claim its Russian origin, the image being introduced into Romanian Orthodox iconography following the war between the Russians and the Turks, in Transylvania its influence could actually be Western. During that period writings like the Catholic hymn Stabat Mater had just been translated. Engravings on the subject were widely spread in Transylvania, either coming from abroad or as a product of the Blaj guild of engravers. This image was largely promoted by the Jesuits in their circles. Figure 8 from the iconostasis of St George church in Lupșa shows the Virgin beside Christ's cross with a spare piercing her heart.

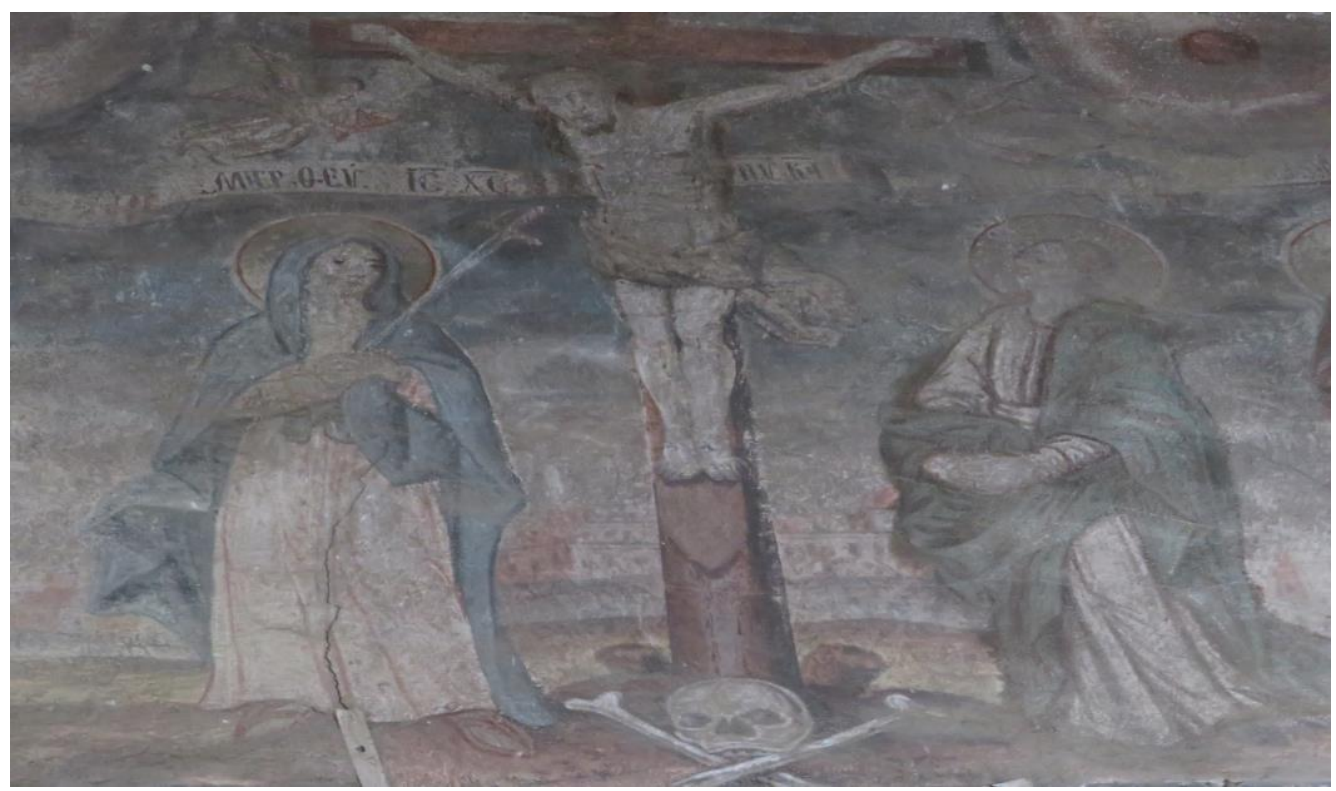

Figure 8. The Crucifixion, Iconostasis, St George Church in Lupșa, Simion Silaghi and his son Simion in 1810

An abundance of angelic representations accompanied those of the Virgin. Whole angels or mere putti heads, a Renaissance influence largely borrowed and promoted later by the Baroque art, embellish some Orthodox churches.

The figure below shows an iconostasis painted by Ion ot Beriu for the church in Geogel. Ion ot Beriu still observes much of the neo-Byzantine style in his painting in contrast with the painting done in the nave of the same church nearly 15 years later by popa Gheorghe Tobias from Abrud which is characterized by more Western elements. 


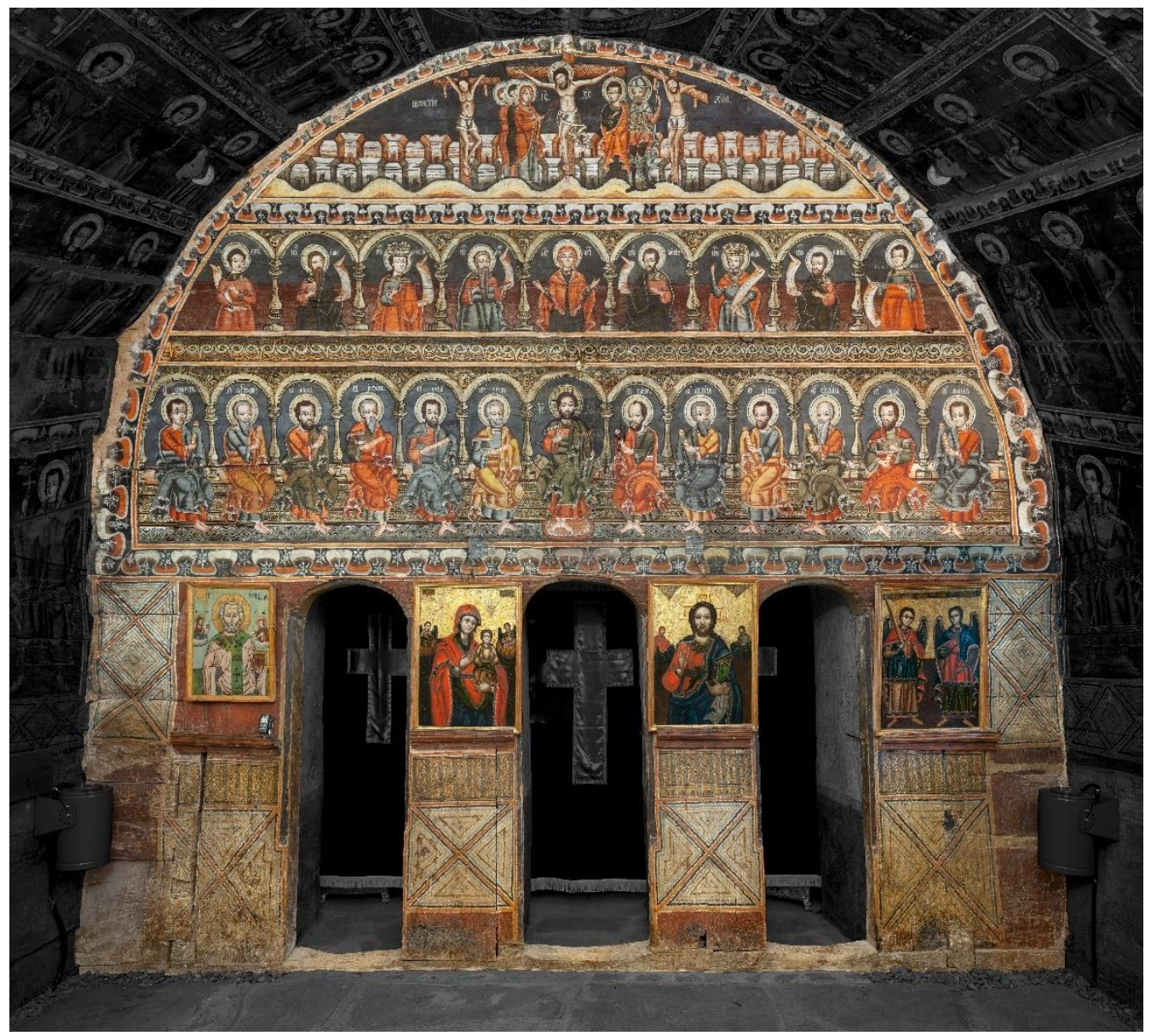

Figure 9. The Iconostasis of St. Archangels' church, Geogel, Ion ot Beriu, 1756

Also, representations of Arma Christi as individual scenes developed during that period.

Although the subject is inspired by Western engravings, its representation is often slightly changed in order to bring it closer to Orthodox art. For example, the depictions of the Beatitudes by Stefan Tenecki, borrowed later by Simion Silaghi were inspired by the Ectypa Bible by Christoph Weigel printed in Augsburg in 1588.56 The Beatitudes were anthropomorphised and were represented as young women in the company of God's angel. One can notice slight changes between the original engravings and the Baroque paintings of Stefan Tenecki or the more naïve representations made by Simion Silaghi. Painting has yet another instrument to draw attention compared to engravings: colour. The engraving done by Christoph Weigel of the Blessed are the poor in spirit, and the same blessing painted by Stefan Tenecki at the monastery of Krusedol and by Simion Silaghi in the church of Gârda de Sus are shown in Figures 10-12.

56. J. Kolundžija, "Moştenirea Pictorului Stefan Tenecki în Episcopia Sremului," in Patrimoniu și Patrimonializare (ed.) Elena Rodica Colta (București: Ed. Etnologică, 2018), 42-63. 
Baroque influences were manifest in Transylvanian art as early as the $1720 \mathrm{~s}$ in the region of Cluj, first in the Catholic world. Later, they were also adopted in Orthodox art. The garments are lavish, the colours are lively with powerful contrasts and the faces have a more realistic touch. The characters are often represented while moving, the angels are sometimes depicted in flight. The flight is suggested by the movement of their clothes and of their wings. Baroque painting is characterized by movement, change and transformation, unlike the traditional Orthodox art in which the characters are static and the focus is laid on inner change.
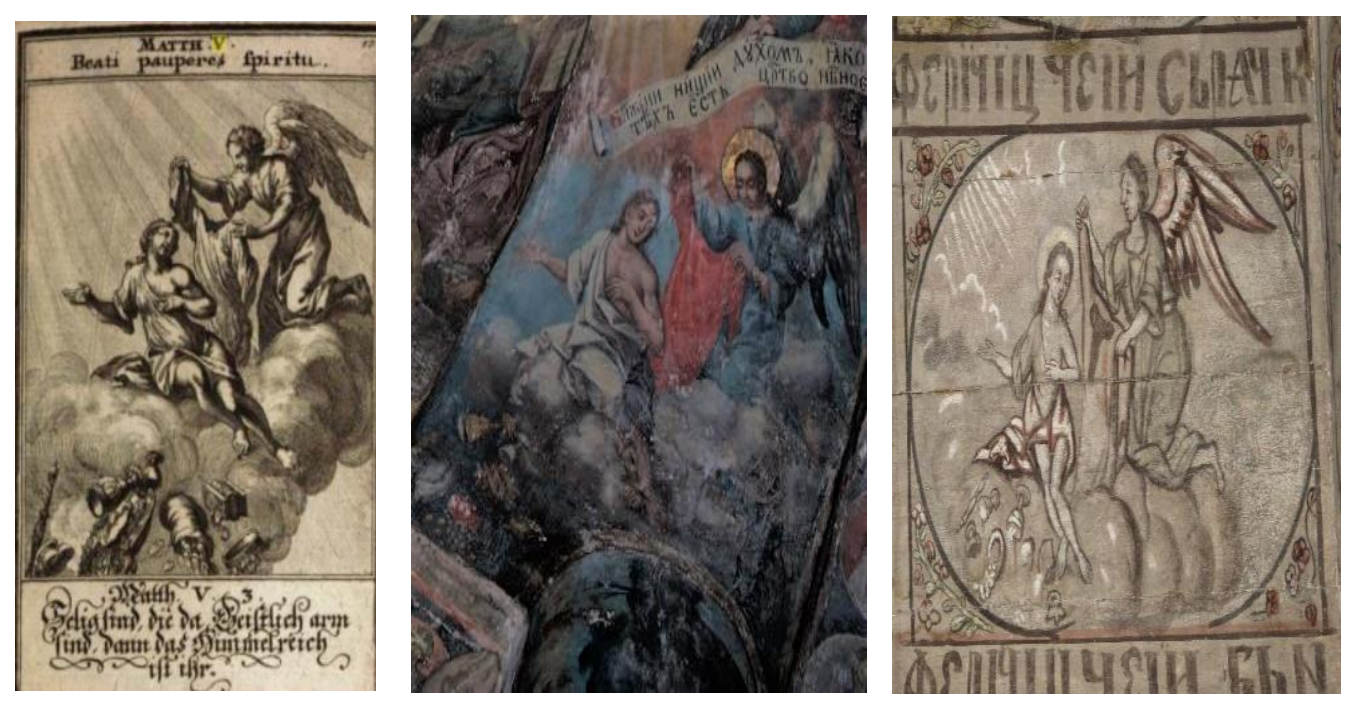

Figures 10-12. The Beatitudes by Christoph Weigel for Biblia Ectypa, 1695, the Triumphal Arch in the Church of the Monastery of Krusedol by Stefan Tenecki, 1745-1757 and the Triumphal Arch, The Nativity of St John the Baptist Church in Gârda de Sus, Simion and Gavril Silaghi, 1804

The representations of nature and buildings are also influenced by Baroque art. Linear and reverse perspectives are used at the same time in the development of certain scenes. They are obvious especially in the depiction of interior scenes, such as the Annunciation, the Nativity of the Virgin or the Beheading of Saint John the Baptist.

Apocalyptic scenes are more often represented as a consequence of conflict, death and lack of social and political equity. They are often inspired by Western models of wood carvings or woodcuts and from Blockbücher. Whereas in Wallachia, Apocalyptic scenes replace The Last Judgement representations in the vestibule or the nave, ${ }^{57}$ in Transylvania, both Apocalyptic and Last Judgement

57. Cornelia Pilat, "Note Despre Unele Reprezentări ale Apocalipsei în Pictura Medievală Românească," in Variațiuni pe Teme Date în Arta Medievală Românească (București: Ed. Vremea, 2003), 139-182. 
scenes are represented. Figure 13 presents a painting of the 24 Elders before the throne of God made by Simion Silaghi in the nave of St. Nicholas church in Ponor.

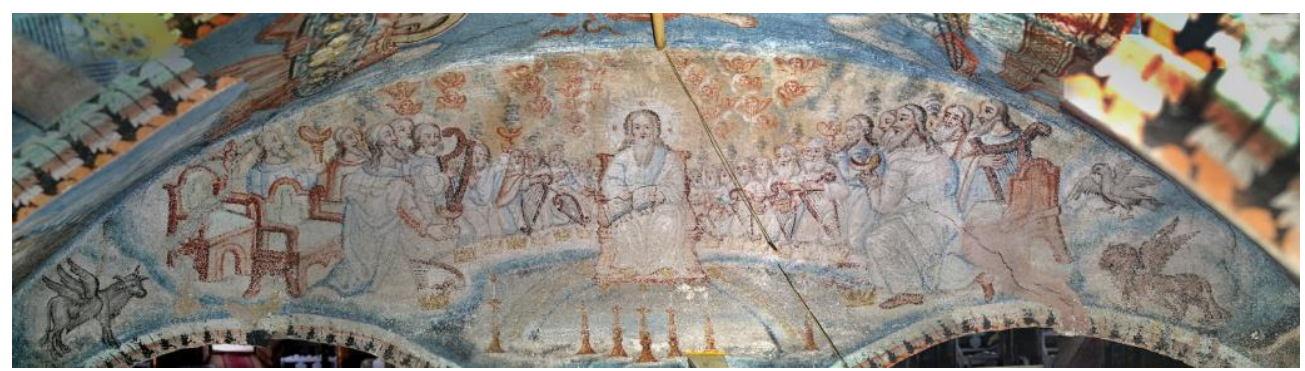

Figure 13. The 24 Elders before the Throne of God, St Nicholas Church in Ponor, 1823, Simion Silaghi

The painting in the church represents the dimension of the world to come and that is why Orthodox painters use the reverse perspective and why anatomic proportions are not generally respected. The task of the Orthodox painter is to reproduce inner grace. However, during the $18^{\text {th }}$ century, the traits of the portraits are more realistic and proportions begin to be observed, especially by the more accomplished painters. As in the Ruthenian lands, two types of art develop: a popular one and a schooled one.

Transylvania was a land of overlapping cultures, of many influences which are manifest in art.

\section{Self-Portraits as a Sign of Raising Awareness}

A level of awareness of the painters' own value and of their search for social status is shown by the fact that during that period several painters' self-portraits are painted in contrast with the traditional view of the humble Orthodox painter that should not make his identity known. In Wallachia the famous painter Pafnutie had already painted several self-portraits at the end of the $17^{\text {th }}$ century at: Filipeștii de Pădure in 1692, Holy Archangels Berca in 1694 and Bordești in 1699. During the following century several other Wallachian painters also painted their self-portraits. One of the best known is that of painter Nicolae Polcovnicu in 1818. 


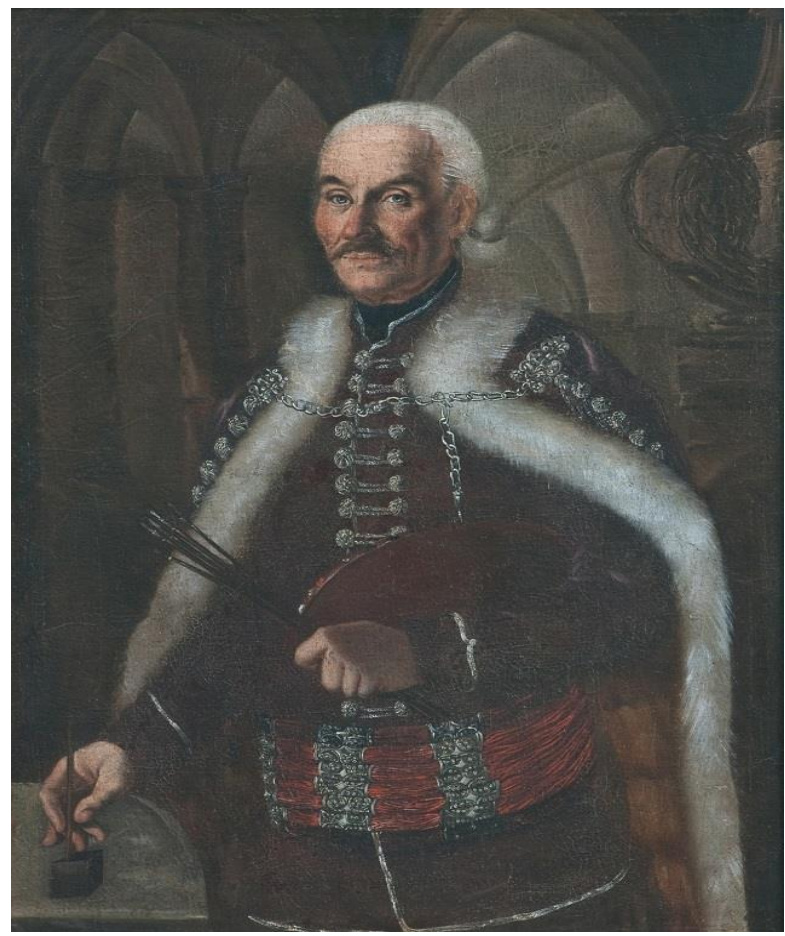

Figure 14. Self-Portrait of Stefan Tenecki, 1770

In Banat one of the best-known self-portraits is that of Stefan Tenecki, dating from 1770 shown above, the master of Baroque art, who also held an influential position in the city council of Arad. This is the first self-portrait in Serbian art. Other painters who painted their self-portraits are Radu Munteanu from Maramuresh in the church of Ungureni in 1782 and Ștențel Condrat from Bistrița in Transylvania in the church of Săcalu de Pădure in 1818.58

\section{A Short Semantic Analysis of Painters' Signatures}

The Western influences were manifest also at the level of the painters' signatures. The $18^{\text {th }}$ century was a time in which even the most gifted painters had their quests and temptations which shaped several stages in their careers. At certain stages in their careers by making use of the artistic or technical means of the period they departed from the rules of the liturgical art as it had been canonized in the writings of the fathers of the church. "The works of these painters were not only the result of their true and deep spiritual experience, expressed through ascetism and prayer, but also handwork in the most literal sense, evoked by the expression 'by the hand of'." 59

58. Ioana Cristache Panait, "Tipuri Sociale și Aspecte de Critică Socială în Pictura Monumentelor de lemn din Centrul și Vestul Țării," 1984, 56.

59. Dumitran, Cucui, Mihu and Pop, Iacov Zugravul, 2010, 85. 
Iacov from Răşinari after a certain stage of his career began signing his works using the title of boyar, a local nobleman. This might also be linked to his supposedly conversion to the Greek Catholic church following in the steps of his former master, Grigore Ranite. Another painter, Simion Silaghi signed his works using the title of painter of Abrudbania.

This was not an unusual practice for the Orthodox painters under Habsburg rule, for example the well-known painter from Muncaci, Ilia Brodlakovici Vişenski signed as "maljar Mukachevskyj". ${ }^{60}$ Painters usually attached to their name, the name of their region or place of origin, as did Toader and Iacov Ciungar or father Nicolae of Feisa.

Foreign appellatives, like Piktor of Latin origin and the German Mahler were often employed by painters. However, painters' signatures, like those of Stan or Iacov from Rășinari prove that the old appellative zugrav or zograf of Slavic origin was still largely used. Sometimes the same painter would employ several different appellatives. This was the case of Simion Silaghi who signed both piktor and zugrav, perhaps depending on the community that commissioned the work as shown in Figures 15-16, while Stefan Tenecki is mentioned in official documents with the appellative of Mahler or Maler.$^{61}$ Furthermore, Simion Silaghi also resorted at times to the Magyarization of his name signing Simon Szylagi. ${ }^{62}$ Ruthenian painters like Andrei Haljeckyj and his son, Nicolai Hajeckyj, ${ }^{63}$ or for Marco Shestakovych ${ }^{64}$ used the same foreign appelatives. Furthermore, during the $18^{\text {th }}$ century a painter called Ioan Maliar (John the Painter) worked in Maramuresh.
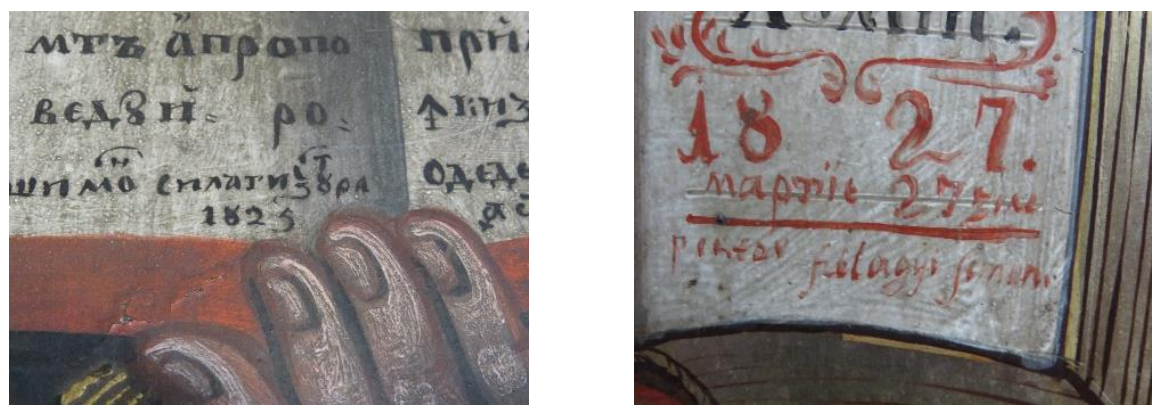

Figures 15-16. Simion Silaghi's Signatures on the Icon of Christ in Corna, 1825 and in Bucium Muntari, 1827

\section{Reasons for Change}

60. Iconography, Sacred Painting in Subcarpathian Ruthenia (Byzantine Seminary Press) Available at: https://www.archpitt.org/iconography-sacred-painting-insubcarpathian-ruthenia/.

61. Porumb Dicționar de Pictură Veche Românească din Transilvania, 1998.

62. Dumitran, "Pictura Românească în Județul Alba până la Mijlocul Secolului al XIXlea. Demersuri Pentru o Bază de Date," Patrimonium Apulense (2012): 62.

63. Iconography, Sacred Painting in Subcarpathian Ruthenia.

64. Berezhnaya and Himka, The World to Come. Ukrainian Images of the Last Judgement, 2015, XIV. 
What triggered these changes in religious painting? Was it just the social and political context? During the $17^{\text {th }}$ century, the Reforms made by Peter Mohyla, followed a century later by those of Emperor Peter the Great had drawn closer Easter Christian religious art to Western religious art. Their influence spread in Transylvania due to the Metropolitanate of Karlowitz. The Orthodox Serbs were more welcoming to elements from Western religious art in their painting as they aimed to prove their equality with the rest of the Christian confessions in the Empire. The professors who worked in the schools of the Metropolitanate came from Imperial Russia. Vasili Romanovici and Job Vasilievici had a great influence on the art promoted in the Metropolitanate. Patriarch Arsenie IV demanded in 1742 that all church painters under his jurisdiction observe the models and the style of Job Vasilievici or be schooled by him. ${ }^{65}$

Lay painters were more sensitive to the tastes of the donors as they depended solely on the income from their commissions. Most of the painters were paid in money. For example, the cost of the painting for the Cathedral in Blaj stood at around 4,000 or 5,000 renans. The cupola costed 400 renans and the inferior level of the iconostasis 300 renans. ${ }^{66}$ Payment in kind was very rare during that period.

Who were the donors? We find the answer in the church inscriptions bearing the names of their donors. Generally, the whole community paid for the building of the church and for its painted decoration, as Ioana Cristache Panait ${ }^{67}$ notes. First of all the inscriptions mention the bishop, then the local priest and the local community.

Were these changes imposed by the donors under the influence of the Metropolitanate of Karlowitz or were they undertaken by the painters and the community as part of their quest for social status and acceptance?

Did they occur as a natural part of the many exchanges that took place among painters?

Painters sometimes travelled far away to meet their commissions. For example, Simion Silaghi travelled all the way from Abrud to Julița in Arad where he might have met for the first time Stefan Tenecki. Later, Tenecki came to Certege nearby Abrud perhaps to study the iconostasis painted by Vasile Zboroschi. He died there and was buried in the graveyard of the parish attended by Simion Silaghi in Abrud.

65. Vladimir Simic, "Political Orthodoxy and Arts: Serbian-Russian Relations Cultural Relations in the 18th Century," Musicology 28 (2020): 86.

66. Sylvester Terdik, “'Sculptor Constantinopolitanus' Un Intalagtiore Greco a Mariapocs nell Settecento in Vegheso Tamas," in Symbolae: Wege der Erfoschung des griechisch-Katolischen Erbes. Aktes den Konferenz zum Andenken an den 100. Todestag von Nikolaus Nilles (Niregyhaza, 2010), 251.

67. Cristache Panait, "Tipuri Sociale și Aspecte de Critică Socială în Pictura Monumentelor de lemn din Centrul și Vestul Țării," 1984, 54. 
Later on, in 1835 three painters worked at the huge iconostasis in Bucium Izbita: Simion Silaghi the Younger, who was following in his father's footsteps and was a local, Anton Simion from Cluj and Dimitrie Dimitriu who had come all the way from Bucharest. These facts underline the painters' mobility.

Iconographers also came into contact with foreign painters or at least with their work. For example, the iconostasis painted by Vasile Zboroțchi in Certege is likely to have had some influence on a number of painters from the region. One of them was Simion Silaghi who also borrowed a lot of elements from Stefan Tenecki and from Gheorghe, son of Iacov, who, himself had been influenced by Grigore Ranite and had done at least a part of his apprenticeship in Wallachia. Grigore Ranite's work in Rășinari and Șcheii Brașovului is likely to have influenced more than one Transylvanian painter.

But were all these changes due only to exterior factors or was there a change of taste inherent to the fact that several nations and confessions were cohabiting and to the desire to be recognized as equals?

A possible answer seems to come from the church in Lupșa, initially painted by priest Gheorghe Tobias from Abrud in 1750. The inscription reads "this sanctuary was painted in 1750 at the expense of the faithful Olia Ion from Lupsa who paid 18 florints for his eternal memory. Ion, Petca, Salomiia, Petca, Matei, Simziana [?], Andrei, Nicolae, Filimon, Ioana". ${ }^{68}$ The painting of the sanctuary and the iconostasis was remade in 1810 by master Simion Silaghi and his son Simion from Abrud. If the painting done by Gheorghe Tobias was in line with the Orthodox tradition, this time a lot of elements of Catholic influence were included in the iconographic programme, like the Immaculate conception on the vault of the sanctuary as shown in Figure 17, Mater Dolorosa at the iconostasis, the Sacred Heart of Jesus on the triumphal arch. They coexisted with traditional Orthodox elements like the representation at the iconostasis of a stylite saint, probably Symion. To our knowledge this is the iconographic programme closest to the Catholic dogma that Simion Silaghi had ever painted. Interestingly, the sanctuary was painted at a time when the church was still Orthodox. It only became Greek Catholic in 1827. Should we consider this evidence of the painter's and the priest's and community's free choice?

68. The inscription is written in Romanian in the Cyrillic alphabet Iar la an $1750 \mathrm{~s}$-au zugrăvit acest sf. oltar din cheltuiala unui creştin de aici din Lupşa, anume Olia Ion au dat 18 florinţi ca să fie veacinică pom[enire]. Ion, Petca, Salomiia, Petca, Matei, Simziana [?], Andrei, Nicolae, Filimon, Ioana". The inscription refers only to the paintings in the altar. 


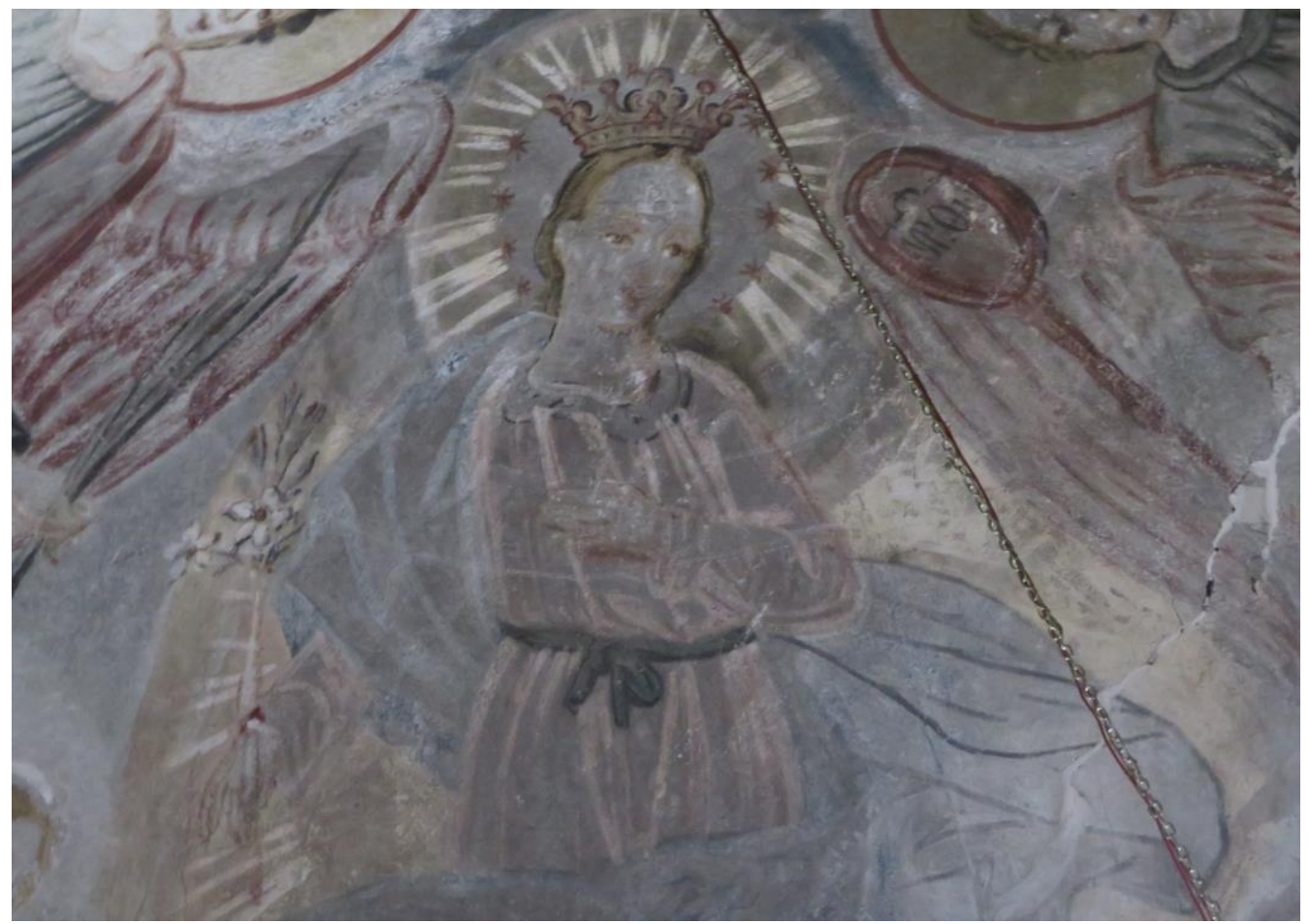

Figure 17. The Immaculate Conception, the Vault of the Sanctuary, St. George Church in Lupşa, 1810

At that time, at the level of religious art, there was no clear opposition between the Orthodox and the Greek Catholic church as Greek Catholic painters such as Gheorghe Tobias painted Orthodox churches and Orthodox painters such as Stefan Tenecki, Iacov of Rășinari, Grigore Ranite and Simion Silaghi also painted Greek Catholic churches.

Furthermore, apparently, Isidor Silaghi's mother, who was Simion Silaghi's grandson, came from the family of the Greek Catholic priest and even bishopric candidate Alpini, a famous family in Transylvania. ${ }^{69}$ The two confessions were united in the quest for social status.

Simion Silaghi also painted the effigy of the Imperial House of Vienna in the church at Ponor in 1823 as a mark of his allegiance to the Emperor.

However, art was not free from social and political influences and sometimes discontent was also made manifest in art. For example, the tormentors in the Passions of Christ scenes wore contemporary robes and this was common practice also in the Ruthenian painting. Christ's sacrifice was brought thus into actuality. Sometimes Pontius Pilate or the great priests Anna and Caiaphas were represented either in Ottoman clothes or Pilate could be depicted as the Pope of Rome. Figure 18 shows Christ before Pilate in a painting from the church in Mogos, Cojocani by Gheorghe, son of Iacov, while Figure 19 shows two images from the Passion Cycle in the nave of the church in Geogel painted by Popa Gheorghe

69. Dumitran, “Pictorul Simion Silaghi-Sălăgeanu. În Căutarea Identităţii,” 2012, 198. 
Tobias. This form of expression was previously used in the scene of the Last Judgement in the frescoes of Sucevița monastery in Moldavia, painted during the $16^{\text {th }}$ century.

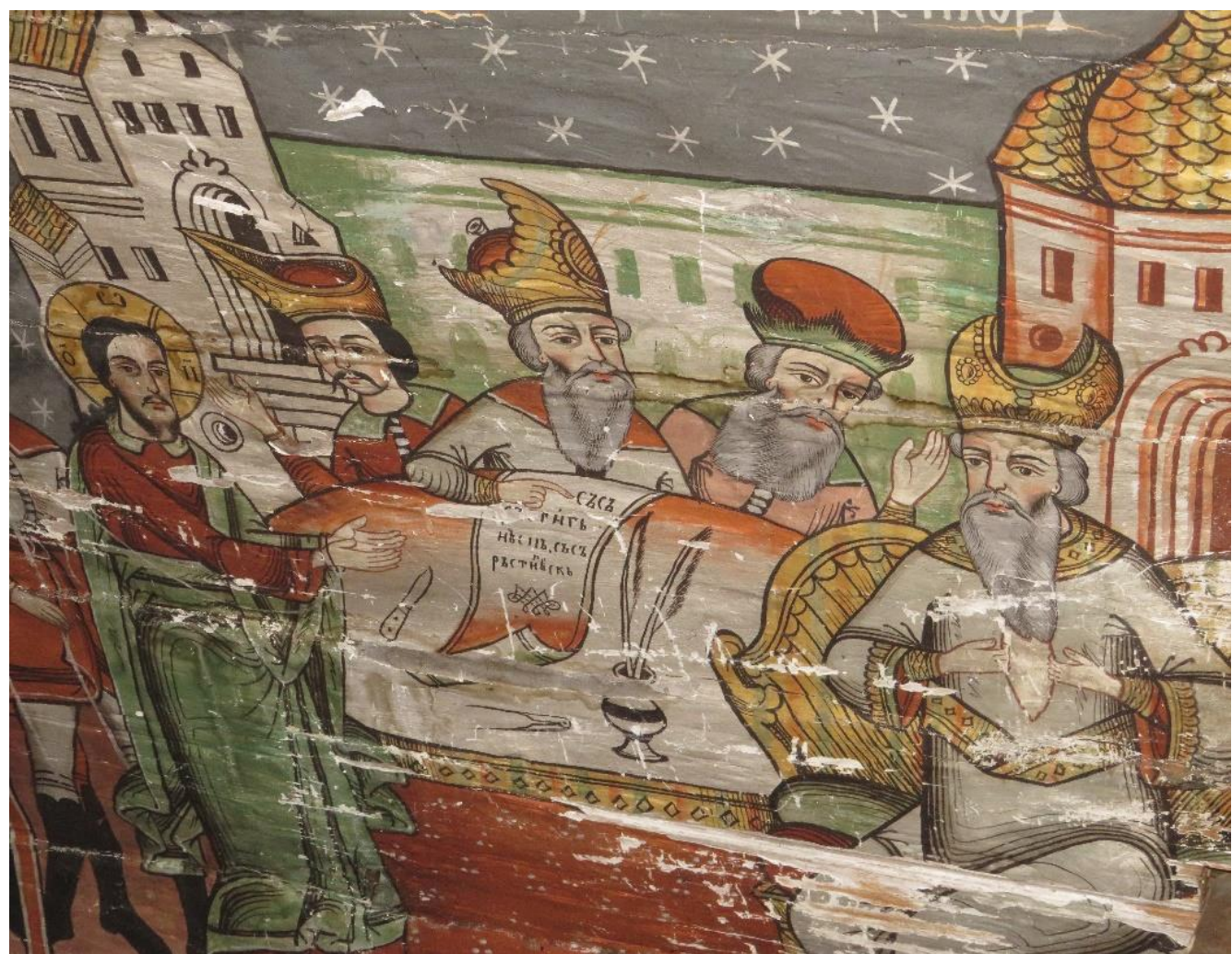

Figure 18. Christ Before Pilat, St. Archangels Church in Mogoș Cojocani, Painter Gheorghe Son of Iacov, 1771

The painting in several churches relates to the uprising of Horea, Cloșca and Crișan from 1784, while on the wall of the church in Bezded, ${ }^{70}$ built and painted between 1755 and 1759 an episode of the Romanians caught and compelled to serve in the Imperial army is depicted.

70. Cristache Panait, "Tipuri Sociale și Aspecte de Critică Socială în Pictura Monumentelor de lemn din Centrul și Vestul Țării," 1984, 59; Cristache Panait, "Valori de Cultură și Artă ce Evocă Răscoala lui Horea, Cloșca și Crișan," RMM MIA XV, no. 2, (1984): 11-20. 


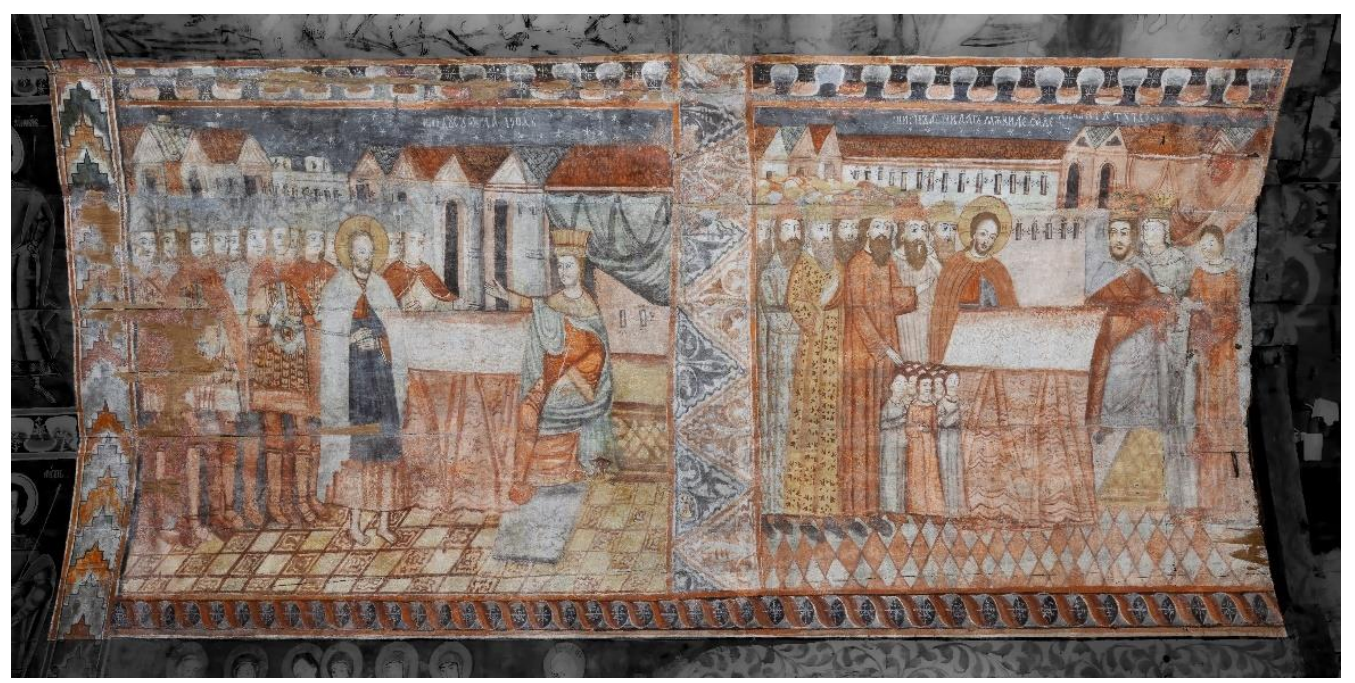

Figure 19. The Passion cycle, Christ before Pilate, St. Archangels' church, Geogel, Popa Gheorghe Tobias, 1770

At the same time, painters such as Simion Silaghi were not left out of this fight for social and political rights. In a painting made towards the end of his life, depicting the Resurrection of Christ, Simion Silaghi painted the flag of the Eteria movement, a movement of liberation led by Greek patriots, which extended also to Wallachia. The same flag of the Eteria was also represented in an icon of St. Catherine from Wallachia painted during that period. ${ }^{71}$

Isidor Silaghi, also a church painter like his father Simion the Younger, moved to Wallachia in 1857 and gave up church painting becoming instead "a photographer", which at that time meant a painter who depicted contemporary events as he saw them, an illustrator of the Romanian War of Independence in $1877 .{ }^{72}$ In native Transylvania, he was a highly appreciated church painter, his art being considered as "Byzantic" unlike the art of the painters educated in the Western world. The comparison made by priest Moga in a letter addressed to Metropolitan Andrei Șaguna in Sibiu in 1857 refers to painter Constantin Lecca who had been educated abroad in Buda. ${ }^{73}$ The priest claimed that master Isidor had received some money in order to paint two churches in the region of Covasna and that he left to Wallachia without returning the money or delivering the job. Interesting enough, the Byzantine style in that period came to encompass a lot more foreign influences, either Ruthenian or Western. The meaning of the term in the second half of the $19^{\text {th }}$ century was quite different from its meaning several centuries earlier.

71. George Oprescu, Scurtă Istorie a Artelor Plastice în RPR, volume II (București: Editura Academiei, 1958), 12.

72. Paul Rezeanu, "Pictorul Selageanu şi Războiul Nostru de Independență," Revista Muzeelor şi Monumentelor, Muzee 8 (1977): 66.

73. Ana Grama, “Documente Arhivistice Sibiene (1850-1870). Donații din țară și Conflicte cu Autoritățile Locale în Județul Covasna (1851-1859)," Angvstia I (1996): 165-186. 
In 1859 the two Romanian principalities Wallachia and Moldovia united, accomplishing a long lasting Romanian dream. This may be one of the reasons why Isidor chose to move to one of the Romanian Principalities on the eve of their unification.

\section{Conclusion}

In conclusion, the changes in art were imposed by church authorities, but also assumed by local communities and priests who were the main donors of art works. The cohabiting of different cultures and peoples in Transylvania led to exchanges and mutual influences throughout the centuries. Changes in art may have come from a change in taste, the taste of the Romanians growing closer to those of other nations with whom they shared the land. On the other hand, the change in art may show a desire of acceptance and recognition that could be gained only by drawing closer to the style of those who were already accepted and recognized, members of the ruling nations and classes.

Changes also occur at the semantical level. Due to the variety of signatures used by one and the same painter, we can conclude that these changes spring from the desire of the painters to improve their social status and to be recognized as artists, for during that period, painters are no longer craftsmen. They do not need to involve also in other activities for they can gain their life from their commissions. Painters become artists improving their condition and their social status.

At this time, the term Byzantine art was enlarged and came to include other influences manifest in the Orthodox religious art in Transylvania. A century later, the art of the Transylvanian painters was regarded rather as Byzantic compared to that of painters trained in Western schools.

To conclude, the art developed in Transylvania during that time was the result of the cohabiting of several nations that led to a convergence in the tastes of these nations, but also of the rules imposed by the political and religious authorities and of the need for social recognition.

\section{Bibliography}

Berezhnaya, Lilya and John Paul Himka. The World to Come. Ukrainian Images of the Last Judgement. Harvard University Press, 2015.

Brusanowski, Paul. "Statutul Canonic al Ortodoxiei din Spaţiul Intracarpatic până în 1864."(The Canonical Status of Orthodoxy in the Intracarphatic Space until 1864.) Revista Teologică 20, no. 92 (2010): 95-113.

Câmpeanu, Remus, A. Câmpian, et al. In spiritul Europei Moderne. Administrația și Confesiunile din Transilvania în Perioada Reformismului Terezian și Iosefin (1740-1790). (In the Spirit of Modern Europe. The Administration and the Confessions in Transylvania 
During Theresian and Josephine Reforms.) Cluj Napoca: Presa Universitară Clujeană, 2009.

Cerovič, Ljubivoje. Sârbii din România. Din Evul Mediu Până în Zilele Noastre. (The Serbs in Romania. From the Middle Agest to the Present.) Timișoara: Uniunea Sârbilor din România, 2008.

Cristache Panait, Ioana. "Tipuri Sociale și Aspecte de Critică Socială în Pictura Monumentelor de lemn din Centrul și Vestul Țării," (Social Types and Aspects of Social Criticism in the Painting of the Wooden Monuments from the Centre and Western Parts of the Country.) RMM, MIA XV, no. 1 (1984): 54-59.

. "Valori de cultură și artă ce evocă răscoala lui Horea, Cloșca și Crișan." (Values of Culture and Art that Remind the Uprising of Horea, Cloșca and Crișan.) RMM MIA XV, no. 2 (1984): 11-20.

Cvetkovic, Vladimir. "The Serbian Tradition." In The Orthodox Christian World, edited by Augustine Casiday. London: Routledge, 2012.

Deluga, Waldemar. "L'évolution de l'iconographie dans l'église Gréco-Catholique Pendant le XVIII-ieme Siècle à la Lumière des Sources Ecrites." (The Evolution of Iconography in the Greek Catholic Church During the 18th Century According to Written Sources.) Revue des Etudes Slaves LXXI, no. 2 (1999): 225-242.

. Ukrainian Painting Between the Byzantine and Latin Traditions. Ostrava-Warsaw, 2019.

Dragomir, Silviu. Contribuţii Privitoare la Relaţiile Bisericii Româneşti cu Rusia în Veacul XVII, (Contribtutions on the Relations of the Romanian Church with Russia During the 17th Century.) București: Academia Română, 1912.

Dumitran, Ana. “Un Zugrav de Elită: Grigore Ranite." (An Excellent Painter: Grigore Ranite.) Annales Universitatis Apulensis, Series Historica 14, no. I (2010): 83-98.

. "Pictorul Simion Silaghi-Sălăgeanu. În Căutarea Identităţii." (Painter Simion Silaghi Sălăgeanu. In Search of an Identity.) Annales Universitatis Apulensis. Series Historica 16, no. I (2012): 189-228.

. "Pictura Românească în Județul Alba până la Mijlocul Secolului al XIX-lea. Demersuri Pentru o Bază de Date." (Romanian Painting in Alba County until the Middle of the 19th Century. Approaches to a Database.) Patrimonium Apulense (2012). "Între logos și eikon. Un eseu Despre Icoană, Români și Protestantism în Transilvania Secolului al XVII-lea." (Between Logos and Eikon. An Essay on Icon, Romanians and Protestantism in the $17^{\text {th }}$ Century Transylvania.) In Annales Universitatis Apulensis, Series Historica, 18/I. Cluj Napoca: Ed. Mega, 2014.

. "The Chronology of the Murals in the Râmeț Monastic Church. Based on a Reevaluation of the Dating of the Narthex Inscription." Museikon Alba Iulia 4 (2020): 109162.

Dumitran, Ana, Elena Cucui, Elena Mihu and Saveta Pop. Iacov Zugravul. (Iacov the Painter.) Alba Iulia: Ed. Altip, 2010.

Dumitran, Ana et al. Stan Zugravul. (Stan the Painter.) Alba Iulia: Ed. Altip, 2011.

Ghitta, Ovidiu. "Episcopul Iosif de Camillis și Românii din Părțile Ungurești." (The Bishop Iosif of Camillis and the Romanians in the Hungarian Territories.) Studia Universitatis Babeș Bolyai 47, no. 1-2 (1997): 51-74.

Grama, Ana. “Documente Arhivistice Sibiene (1850-1870). Donații din Țară și Conflicte cu Autoritățile Locale în Județul Covasna (1851-1859)." (Donations from the Country and Conflicts with Local Authorities in the County of Covasna (1851-1859).) Angvstia I (1996): 165-186. 
Herrin, Judith. “The Imperial Feminine in Byzantium." Past \& Present, no. 169 (2000): 3-35.

Himka, John-Paul. Last Judgement Iconography in the Carpathians. Toronto: University of Toronto Press, 2009.

Iancovescu, Ioana. "Les Sources Russes et Ukrainiennes de la Peinture murale au Temps de Constantin Brancovan." (The Russian and Ukrainian Sources of the Mural Paintings During the Time of Constantin Brancovan.) Revue Roumaine de l'histoire de l'art Série Beaux-Arts, Tome XLV (2008): 101-116.

Iconography. Sacred Painting in Subcarpathian Ruthenia. Byzantine Seminary Press. Available at: https://www.archpitt.org/iconography-sacred-painting-insubcarpathian -ruthenia/.

Jenei, Dana. Pictură Murală Gotică din Transilvania. (The Gothic Mural Painting in Romania.) București: Noi Media Print, 2007.

Kalopissi Verti, Sophia. "Painters in Late Byznatine Society. The Evidence of Church Inscriptions." Cahiers Archeologiques 42 (1994).

Kolundžija, Jovana. "Moştenirea Pictorului Stefan Tenecki în Episcopia Sremului." (The Heritage of Stefan Tenecki in the Srem Bishopric.) In Patrimoniu și patrimonializare, edited by Elena Rodica Colta. București: Ed. Etnologică, 2018.

Marin Barutcieff, Silvia. "Un Pictor Transilvănean Pierdut...? Ursu Broină." (A Forgotten Transylvanian Painter...? UrsuBroină.) Apulum, no. 50 (2013): 361-378.

Medeleanu, Horia. "The Life of an 18th Century Painter: Stefan Tenetchi." Revue des Études Sud-Est Européennes XXI-2 (1983): 125-145.

Meteș, Ștefan. "Zugravii Bisericilor Române.” (The Painters of the Romanian Churches.) Anuarul Comisiunii Monumentelor Istorice, Secția Pentru Transilvania 1926-1928 (1929).

Mureșan,Vasile and Marcel Naste. Toader Popovici Zugravul. (Toader Popovici the Painter.) Târgu Mureș: Ed. Vatra Veche, 2015.

Oprescu, George. Scurtă Istorie a Artelor Plastice în RPR, volume II. (Short History of Arts in the Socialist Republic of Romania.) București: Editura Academiei, 1958.

Petreanu, Coriolan. Bisericile de Lemn ale Românilor Ardeleni. (The Wooden Churches of Romanians from Transylvania.) Sibiu, 1934.

Pilat, Cornelia. "Note Despre Unele Reprezentări ale Apocalipsei în Pictura Medievală Românească." (Notes on Some Representations of the End of Days in Romanian Medieval Paintings.) In Variațiuni pe Teme Date in Arta Medievală Românească, 139-182. București: Ed. Vremea, 2003.

Plokhy, S. Porțile Europei. O Istorie a Ucrainei. (At the Gates of Europe. A History of Ukraine.) București: Ed. Trei, 2018.

Porumb Marius. Dicționar de Pictură veche Românească din Transilvania (Dictionary of Old Romanian Painting from Transylvania.) București: Editura Academiei Române, 1998. . Un Veac de Pictură Românească din Transilvania, Secolul XVIII. (A Century of Romanian Painting in Transylvania: The 18th Century.) București: Meridiane, 2003.

Prodan, David. Supplex Libellus Valachorum. Din Istoria Formării Națiunii Române. (Supplex Libellus Valachorum. From the History of the Genesis of the Romanian Nation.) București: Ed. Enciclopedică, 2013.

Réau, Louis. Iconographie de l'art Chrétien. Tome II Iconographie de la Bible. (Iconography of Christian Art. Volume II Iconography of the Bible.) Paris: PUF, 1957.

Rezeanu, Paul. "Pictorul Selageanu şi Războiul Nostru de Independenţă." (The Painter Selageanu and our War of Independence.) Revista Muzeelor şi Monumentelor, Muzee 8 (1977). 
Saetveit Miles, Laura. The Virgin Mary's Book at the Annunciation: Reading, Interpretation, and Devotion in Medieval England. D.W. Brouwer, 2020.

Sevcenko, Thor. "The Many Worlds of Peter Mohyla." Harvard Ukrainian Studies 8, no. 1/2 (1984): 9-44.

Simic, Vladimir. "Political Orthodoxy and Arts: Serbian-Russian Relations Cultural Relations in the 18th Century." Musicology 28 (2020).

Terdik, Sylvester. "'Sculptor Constantinopolitanus' Un Intalagtiore Greco a Mariapocs nell Settecento." ('Sculptor Constantinopolitanus', a Greek Sculptor in Mariapocs in the 18th Century.) In Symbolae: Wege der Erfoschung des Griechisch-Katolischen Erbes. Aktes den Konferenz zum Andenken an den 100. Todestag von Nikolaus Nilles. Niregyhaza: Ed. Vegheso Tamas, 2010.

Uspenski, Leonid. Teologia icoanei în Biserica Ortodoxă Rusă. (The Theology of the Icon in the Russian Orthodox Church.) Cluj Napoca: Ed. Patmos, 2005.

Zweig, Philip. Icônes, XI-XVIII Siècles. (Icons: 11-18 Centuries.) New York: Parkstone International, SUA, 2004. 